\begin{tabular}{|c|c|c|}
\hline & International Journal of Current Research in \\
Biosciences and Plant Biology \\
\hline EXCELLENT \\
PUBLISHERS
\end{tabular}

\title{
Diversity, Genetic Erosion and Participatory Evaluation of Rice (Oryza sativa L. and Oryza glaberrima Steud) Varieties in Benin
}

\author{
T.C. Odjo ${ }^{1}$, I. Dossou-Aminon ${ }^{1,2}$, A. Dansi ${ }^{1,2}$ and H. W. Djengue ${ }^{1}$ \\ ${ }^{1}$ Laboratory of Biotechnology, Genetic Resources and Plant and Animal Breeding (BIORAVE), Faculty of Sciences and \\ Technology of Dassa, BP143, Dassa, Benin \\ ${ }^{2}$ Institute of Research, Training and Development on Crops, Animals and Medicinal plants (IRDCAM), 071 BP 28 Sainte Rita, \\ Cotonou, Benin
}

*Corresponding author.

\begin{tabular}{|c|c|}
\hline Abstract & Article Info \\
\hline \multirow{3}{*}{$\begin{array}{l}\text { Rice, is one of the most important food crops that significantly contributes to food security } \\
\text { in Benin. To assess its varietal diversity within the country, } 55 \text { villages randomly selected } \\
\text { throughout different agro-ecological zones were surveyed using participatory research } \\
\text { tools and techniques. Subject to synonymy, } 95 \text { varieties including } 2 \text { African rice (Oryza } \\
\text { glaberrima) and } 93 \text { Asian rice (Oryza sativa) were inventoried. The Shannon Diversity } \\
\text { Index (H) is } 5.62 \text { and reflects an important varietal diversity. The number of varieties } \\
\text { recorded varies from } 2 \text { to } 9 \text { per village ( } 4 \text { on average). In villages where varietal diversity } \\
\text { is threatened, the rate of loss, subject to synonymy, varied from } 25 \% \text { to } 75 \% \text { with an } \\
\text { average rate of } 41 \% \text { per village. Across villages, the varieties to be produced are selected } \\
\text { on the basis of sixteen (16) preference criteria, of which the most important are high } \\
\text { productivity ( } 18.22 \% \text { responses), market value ( } 14.52 \% \text { of responses), early maturity of } \\
\text { varieties ( } 10.48 \% \text { of responses) and taste ( } 6.92 \% \text { of responses). Thirteen (13) production } \\
\text { constraints were reported by the producers and most of them can be overcomed by the use } \\
\text { of high-performing varieties. Participatory evaluation revealed very few effective varieties } \\
\text { with regard to biotic and abiotic parameters. The development in Benin of a strong and } \\
\text { concerted national rice breeding program is necessary and will help creating novel } \\
\text { varieties that will boost national production, food security and income generation. }\end{array}$} & $\begin{array}{l}\text { Accepted: } 24 \text { February } 2017 \\
\text { Available Online: 06 April } 2017\end{array}$ \\
\hline & Keywords \\
\hline & $\begin{array}{l}\text { Participatory evaluation } \\
\text { Preference criteria } \\
\text { Rice } \\
\text { Varietal diversity }\end{array}$ \\
\hline
\end{tabular}

\section{Introduction}

Rice is the primary food source for more than half of the world's population (Roy et al., 2016). Worldwide, paddy production is estimated at 741.3 million tonnes (494.4 million tonnes, in milled rice equivalent) (FAO, 2015). In Africa it is an essential component of sustainable development, as a major contribution to food security and balance, but also as an important source of income and employment for the poorest populations. On this continent, rice consumption increases faster than that of any other staple food, approximately $5.5 \%$ per year (Seck et al., 2012). This increase is mainly due to changes in eating habits and population growth (USDA, 2013; Seck et al., 2012). Its production increases by an average of 1 to $1.76 \%$ for the period 1991-2001 to more 
than double (3.96\%) for the period 2002-2013 (FAO, 2014).

In Benin, rice sector is with over 206943 tonnes of paddy, the most dynamic agricultural sectors. Total paddy rice production increased from 48,607.00 tonnes in 2000 to 206943 tonnes in 2013 (FAO, 2014). Despite this increase in production, the rice sector faces major constraints such as yield-limiting factors (drought or excess water, lack of nutrients, extreme temperatures), biotic factors (insects, diseases, weeds, birds), and socioeconomic issues (market access, access to knowledge and technology, etc.) (Saïto et al., 2015). These various constraints cannot be overcomed without the knowledge of varietal diversity, variety performances and farmers' preferences. It is widely recognized that varietal diversity used by farmers is an integral part of agrobiodiversity and contributes sustainability to agricultural production systems, especially in subsistence agriculture (Jarvis et al., 2007; Jackson et al., 2010; Altieri et al., 2011; Radanielina et al., 2013). However, strategies to maintain this diversity without hampering agricultural productivity remain to be constructed (Brush, 2000). Thus, knowledge of the determinants of varietal diversity can contribute to the development of such strategies. Unfortunately in Benin, very little work has been done on the inventory, collection, characterization, ethnobotanical investigation, evaluation and conservation of rice varieties (Adeyemi and Vodouhè 1996; Akakpo, 2011; Agnoun et al., 2012). We present in this paper the results of an ethnobotanical investigation conducted to:

- Document the constraints of the production as perceived by the rice farmers;

- Assess the varietal diversity of rice;

- Assess in a participatory way the agronomic, technological and culinary characteristics of the existing varieties;

- Identify the farmers' varietal preference criteria and understand their variation throughout agroecological zones;

\section{Materials and methods}

\section{Study area and sampling method}

This study was carried out in Republic of Benin, a country of West Africa covering $114763 \mathrm{~km}^{2}$ ). Across the country, average annual temperatures range from 26 to $28^{\circ} \mathrm{C}$ and the rainfall is between 900 and $1400 \mathrm{~mm}$ per year with a west-east gradient and a south-north gradient. The population of Benin is estimated at 9,983,884 inhabitants divided into a mosaic of sociolinguistic groups (INSAE, 2013) based on the results of the average rice production of the period of 1998-2013 (MAEP, 2013), 36 districts and 55 villages (Fig. 1) were randomly selected for the survey.

Within village, the size of the sample (farmers) is obtained using the normal approximation to the binomial distribution proposed by Dagnelie (1998):

$$
N=\frac{\left(U_{1-\frac{\alpha}{2}}\right)^{2} \times P(1-p)}{d^{2}}
$$

With $U_{1-\frac{\alpha}{2}}$, the value of the normal random variable for the probability value of $1-\alpha / 2, \alpha$ being the risk of error. For $\alpha=5 \%$, the probability $1-\alpha / 2=0.975$ and we have a $U_{1-\frac{\alpha}{2}=1.96} \quad ; \mathrm{P}$ is the proportion of people engaged in rice production in the study environment, and the margin of error for estimation is $8 \%$ in this study (Assogbadjo et al., 2011). On the basis a total of 1033 producers were surveyed in the study area. They are distributed in the production areas according to the importance of rice production.

\section{Data collection}

In each village, data were collected using participatory research methods (group surveys and field visits) according to Orobiyi et al. (2013) and Agré et al. (2015a,b). By village, a group of 20 to 30 rice producers of both sexes and ages were identified and brought together with the help of the chief of the village or the responsible of the producers' association. The biological constraints of rice production were listed by the producers in groups and prioritized by the method of identification and progressive elimination of the most important constraint described by Dansi et al. (2013a). In each village, varietal inventory was done in a participatory manner according to Kombo et al. (2012). The distribution and extent of the listed varieties were assessed using the participatory four-square analysis method according to Gbaguidi et al. (2013). This approach allows to classify into four categories (varieties produced by many households over large areas, varieties produced by many households on small areas, varieties produced by few households over large areas and varieties produced by few households on small areas) varieties produced at village level. 


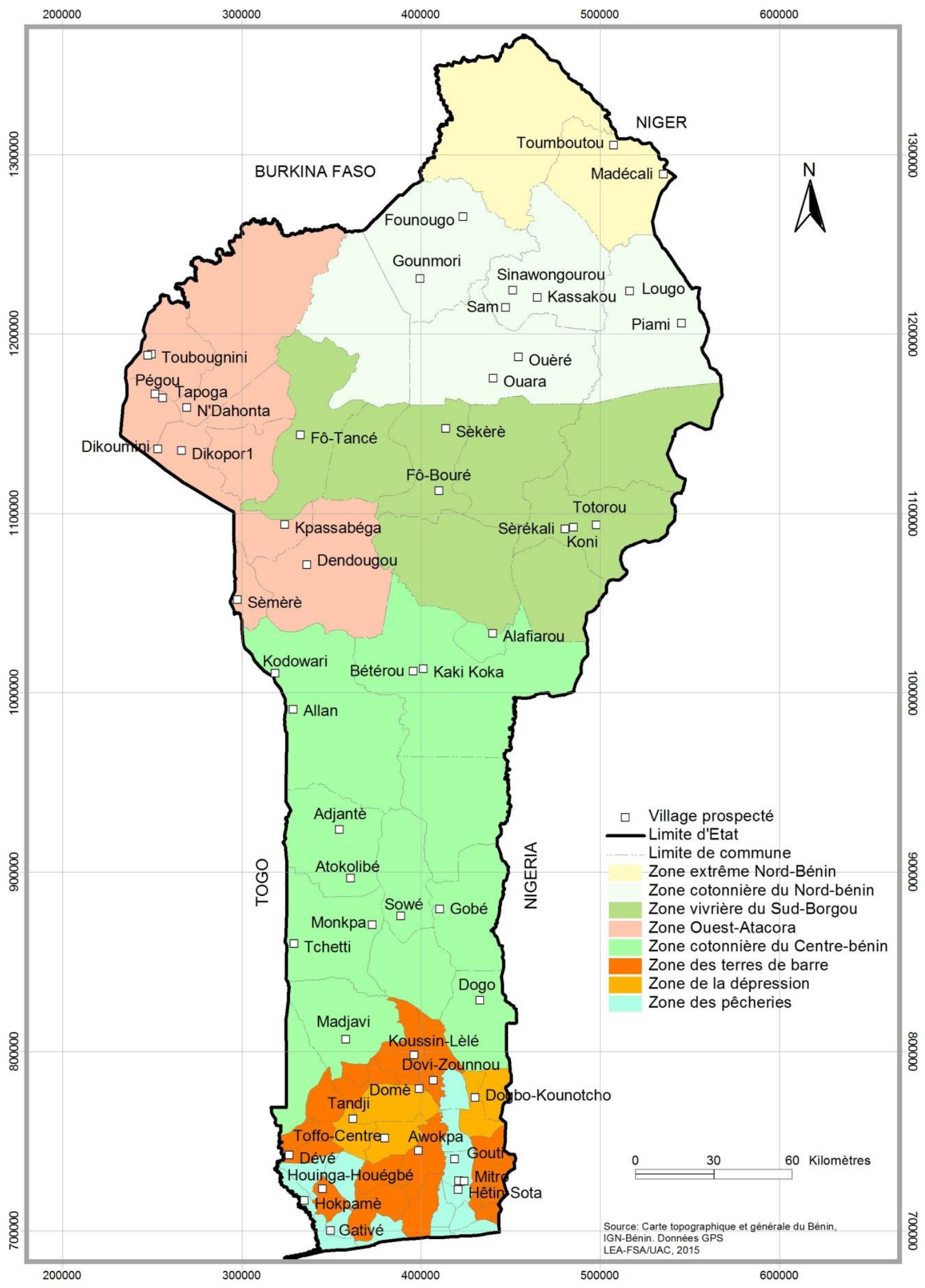

Fig. 1: Map of Benin showing the geographical localization of the villages surveyed. 
The discussions were then conducted on each variety with the aim of understanding their status. Therefore, the reasons for growing each variety by few or many households and on small or large areas have been identified (Gbaguidi et al., 2013). The four squares analysis approach allows the identification of elite varieties (those grown on large areas and by many households in at least one of the villages surveyed) and the assessment of the rate of varietal diversity loss. In each village surveyed and in a group, each variety was evaluated for a set of agronomic (Productivity, Cycle, Tolerance to drought, Lodging tolerance, Tolerance to Pyriculariosis, Field resistance to insects, Sensitivity to birds), technological (Breaking rate) and culinary (Fast cooking, Cooking yield, Taste) variables. To prioritize farmers' varietal preference criteria two methods are used. These are individual survey with comparison matrix method (Dansi et al., 2010) and group survey (Gbaguidi et al., 2013). In the case of this study, the group method is used. To do this, producers, in each village, were asked to list in group the characteristics that a variety of rice must have to be widely adopted. These preference criteria were ranked according to their importance (\% of the number of villages in which each criterion is cited).

\section{Data analysis}

The data obtained during the surveys were analyzed by the descriptive statistics (mean, percentage, variance, etc.) using the Excel spreadsheet. The constraints identified in each village and grouped by degree of importance were prioritized according to Orobiyi et al. (2013) based on the average of the following three parameters: number of villages in which the constraint is quoted (TNV); Number of villages in which constraint is perceived as principal constraint (PC); Number of villages in which the constraint is qualified as major or classified between the first five (MC). For each of these parameters, the higher the value, the most important the constraint. Thus, the importance of a constraint was determined by the following formula $\mathrm{IMC}=(\mathrm{TNV}+\mathrm{PC}+\mathrm{MC}) / 3$. The rate of loss or threat of varieties at the village level was calculated according to Gbaguidi et al. (2013) using the formula $\mathrm{RDL}=[(\mathrm{nk}) /$ $\mathrm{N}] \times 100$ with $\mathrm{n}$ : number of varieties disappearing, $\mathrm{k}$ : number of newly introduced varieties and $\mathrm{N}$ : total number of varieties in the village. The Shannon diversity index (H) (Shannon and Weaver, 1948), which assesses the importance of diversity is calculated for the study area according Gbaguidi et al., (2013). The diversity is low when $\mathrm{H}$ is less than 3 bits, average if $\mathrm{H}$ is between 3 and 4 and high when $\mathrm{H}$ is greater than or equal to 4 bits (Legendre and Legendre, 1984; Frontier and Pichod-Viale, 1995).

In order to analyze the degree of resemblance between varieties, these were considered as individuals and the 11 evaluation parameters mostly used by producers as variables for running a cluster analysis and a discriminant Factor Analysis (DFA) were performed with the XLSTAT 2016.05 software.

To evaluate the parameters that influence the varietal diversity maintained per household, the MULTILOGIT model of SAS software version 9.2 was used for multiple logistic regression. It focused on the dependent variable "number of varieties maintained per household" with the independent variables that are: sex; age; level of instruction ; marital status ; religion; year of experience; household size; valid arms and the belonging to an association. Pearson $\mathrm{Chi}^{2}$ test was used to assess the determinants that influence the number of varieties maintained per household. To analyze the links between the varietal selection criteria of Benin producers and the agro-ecological zones, data from the different agroecological zones were subjected to a Principal Component Analysis (PCA) with the Minitab software14.

\section{Results}

\section{Sociodemographic characteristics of the respondents, importance and constraints of rice cultivation}

Rice farmers surveyed were in majority (66.70\%) men. Their age ranged from 24 to 73 years with an average of 46 years. The majority $(84.02 \%)$ was between 24 and 53 years hold. Producers' households are largely under lettered (71.64\%). Producers' households size range from 1 to 29 people with an average of 12 people per household. Households with 5 to 20 people are in majority $(85.19 \%)$. Field activities linked to rice production are mainly carried out by the members of the household $(74.93 \%)$ and if necessary by an external labor force (laborers, self-help groups) $(25.07 \%)$. In the study area, the great majority $(89.74 \%)$ of the rice producers cultivate areas ranging from 0.2 to 2.2 ha. $65.25 \%$ of producers classify rice in first $(28,56 \%$ of responses) or in second (36.69\% of responses) position. In the study area, rice is produced for food $(32.43 \%)$ and for economic $(67.57 \%)$ reasons. 
Thirteen constraints related to rice production were identified and prioritized in the study area (Table 1). Among these, the most important is the avian pressure reported in 51 villages, ranked 7 times as the main constraint (ranked first) and in 45 villages as a major constraint (ranked among the top five). This constraint is followed by weed proliferation, inadequate lowlands, pests and disease damage (Table 1).

Table 1. List and importance of rice production constraints in Benin.

\begin{tabular}{llllll}
\hline \multirow{2}{*}{ Constraints } & \multicolumn{2}{l}{ Number of villages } & \multirow{2}{*}{ Average } & \multirow{2}{*}{ Rank } \\
\cline { 2 - 5 } & TNV & PC & MC & & 1 \\
\hline Bird Damage (Avian Pressure) & 51 & 7 & 45 & 34.33 & 1 \\
Proliferation of Weeds & 39 & 6 & 23 & 22.67 & 2 \\
Insufficient lowland arranged & 38 & 3 & 24 & 21.67 & 3 \\
Pests and disease damage (stem borers, termites, blast, etc.) & 37 & 3 & 24 & 21.33 & 4 \\
Insufficient performant varieties & 39 & 4 & 14 & 19.00 & 5 \\
lack of weed-tolerant varieties & 32 & 4 & 21 & 19.00 & 6 \\
Lack of a well organised market & 35 & 1 & 17 & 17.67 & 7 \\
Lower productivity at variety level & 23 & 4 & 17 & 14.67 & 8 \\
Poverty of the lowlands & 15 & 1 & 10 & 8.67 & 9 \\
Climate variability & 19 & 0 & 5 & 8.00 & 10 \\
Insufficient of early maturing varieties & 10 & 2 & 9 & 7.00 & 11 \\
Drought & 12 & 3 & 9 & 8.00 & 12 \\
Flooding & 9 & 0 & 6 & 5.00 & 13 \\
\hline
\end{tabular}

TNV: total number of villages citing constraint, PC: number of villages that cited the main constraint, MC: number of villages for which the constraint is major, that is to say among the first five.

\section{Varietal diversity and analysis of the distribution and extent of the varieties}

In the study area, the number of rice varieties varies from 2 to 9 with an average of 4 varieties per village (Table 2). In total, subject to synonymies, 95 different names of rice varieties were identified across the 55 villages surveyed. The highest diversity ( 9 varieties) was observed in Founougo (Banikoara) and the lowest (2 varieties) was recorded in 19 villages including Lougou (Ségbana) and Awokpa (Zè) (Table2). Agroecological Zone I has the highest diversity with an average of 6 varieties per village and the lowest is observed in zones VI and VIII (2 varieties per village). However, there is a variation in the number of varieties per village within the same area (Table 2).

Table 2. Diversity, distribution, extent and rate of loss of varieties per village.

\begin{tabular}{|c|c|c|c|c|c|c|c|c|c|}
\hline \multirow{2}{*}{ S.No. } & \multirow{2}{*}{ Village } & \multirow{2}{*}{ NTV } & \multicolumn{4}{|c|}{ Distribution and extent } & \multirow{2}{*}{ NNIV } & \multirow{2}{*}{ NVD } & \multirow{2}{*}{$\operatorname{RLD}(\%)$} \\
\hline & & & $\mathrm{H}+\mathrm{A}+$ & $\mathrm{H}+\mathrm{A}-$ & H-A+ & H-A- & & & \\
\hline 1 & Adjantè & 4 & 1 & 0 & 0 & 3 & 0 & 3 & 75.00 \\
\hline 2 & Piami & 3 & 1 & 0 & 0 & 2 & 0 & 2 & 66.67 \\
\hline 3 & Gounmori & 3 & 1 & 0 & 0 & 2 & 0 & 2 & 66.67 \\
\hline 4 & Wara & 3 & 1 & 0 & 0 & 2 & 0 & 2 & 66.67 \\
\hline 5 & Fô-bouré & 3 & 1 & 0 & 0 & 2 & 0 & 2 & 66.67 \\
\hline 6 & Tapoga & 3 & 1 & 0 & 0 & 2 & 0 & 2 & 66.67 \\
\hline 7 & Dendougou & 3 & 1 & 0 & 0 & 2 & 0 & 2 & 66.67 \\
\hline 8 & Kodowari & 3 & 1 & 0 & 0 & 2 & 0 & 2 & 66.67 \\
\hline 9 & Atokolibé & 3 & 1 & 0 & 0 & 2 & 0 & 2 & 66.67 \\
\hline 10 & Tandji & 3 & 1 & 0 & 0 & 2 & 0 & 2 & 66.67 \\
\hline 11 & Sinawongourou & 5 & 2 & 0 & 0 & 3 & 0 & 3 & 60.00 \\
\hline 12 & Alafiarou & 5 & 1 & 0 & 0 & 4 & 1 & 3 & 60.00 \\
\hline 13 & Dikoumini & 7 & 2 & 0 & 0 & 5 & 1 & 4 & 57.14 \\
\hline 14 & Lougou & 2 & 1 & 0 & 0 & 1 & 0 & 1 & 50.00 \\
\hline 15 & Ouèrè ou Wèrè & 6 & 3 & 0 & 0 & 3 & 0 & 3 & 50.00 \\
\hline 16 & Koni & 2 & 1 & 0 & 0 & 1 & 0 & 1 & 50.00 \\
\hline 17 & Fô-tancé & 4 & 2 & 0 & 0 & 2 & 0 & 2 & 50.00 \\
\hline 18 & N'dahonta & 4 & 1 & 1 & 0 & 2 & 0 & 2 & 50.00 \\
\hline
\end{tabular}




\begin{tabular}{|c|c|c|c|c|c|c|c|c|c|}
\hline \multirow{2}{*}{ S.No. } & \multirow{2}{*}{ Village } & \multirow{2}{*}{ NTV } & \multicolumn{4}{|c|}{ Distribution and extent } & \multirow{2}{*}{ NNIV } & \multirow{2}{*}{ NVD } & \multirow{2}{*}{ RLD (\%) } \\
\hline & & & $\mathrm{H}+\mathrm{A}+$ & $\mathrm{H}+\mathrm{A}-$ & H-At & H-A- & & & \\
\hline 19 & Sèmèrè & 2 & 1 & 0 & 0 & 1 & 0 & 1 & 50.00 \\
\hline 20 & Kpassabéga & 4 & 2 & 0 & 0 & 2 & 0 & 2 & 50.00 \\
\hline 21 & Allan & 2 & 1 & 0 & 0 & 1 & 0 & 1 & 50.00 \\
\hline 22 & Tchetti & 2 & 1 & 0 & 0 & 1 & 0 & 1 & 50.00 \\
\hline 23 & Monkpa & 2 & 1 & 0 & 0 & 1 & 0 & 1 & 50.00 \\
\hline 24 & Gobé & 2 & 1 & 0 & 0 & 1 & 0 & 1 & 50.00 \\
\hline 25 & Domè & 4 & 2 & 0 & 0 & 2 & 0 & 2 & 50.00 \\
\hline 26 & Houinga-houégbé & 2 & 1 & 0 & 0 & 1 & 0 & 1 & 50.00 \\
\hline 27 & Hokpamè & 2 & 1 & 0 & 0 & 1 & 0 & 1 & 50.00 \\
\hline 28 & Toffo - centre & 2 & 1 & 0 & 0 & 1 & 0 & 1 & 50.00 \\
\hline 29 & Awokpa & 2 & 1 & 0 & 0 & 1 & 0 & 1 & 50.00 \\
\hline 30 & Founougo & 9 & 2 & 1 & 0 & 6 & 2 & 4 & 44.44 \\
\hline 31 & Bétérou & 7 & 1 & 1 & 1 & 4 & 1 & 3 & 42.86 \\
\hline 32 & Pègou & 7 & 3 & 1 & 0 & 3 & 0 & 3 & 42.86 \\
\hline 33 & Sam & 5 & 1 & 2 & 0 & 2 & 0 & 2 & 40.00 \\
\hline 34 & Sèkèrè & 5 & 2 & 0 & 1 & 2 & 0 & 2 & 40.00 \\
\hline 35 & Totorou & 5 & 2 & 0 & 0 & 3 & 1 & 2 & 40.00 \\
\hline 36 & Kondo & 8 & 3 & 0 & 0 & 5 & 2 & 3 & 37.50 \\
\hline 37 & Tomboutou & 3 & 2 & 0 & 0 & 1 & 0 & 1 & 33.33 \\
\hline 38 & Sérékali & 3 & 2 & 0 & 0 & 1 & 0 & 1 & 33.33 \\
\hline 39 & Toubougnini & 6 & 3 & 0 & 0 & 3 & 1 & 2 & 33.33 \\
\hline 40 & Dipokor 1 & 6 & 3 & 0 & 0 & 3 & 1 & 2 & 33.33 \\
\hline 41 & Sowé & 3 & 2 & 0 & 0 & 1 & 0 & 1 & 33.33 \\
\hline 42 & Madjavi & 6 & 3 & 1 & 0 & 2 & 0 & 2 & 33.33 \\
\hline 43 & Dogo & 3 & 2 & 0 & 0 & 1 & 0 & 1 & 33.33 \\
\hline 44 & Madécali & 8 & 4 & 2 & 0 & 2 & 0 & 2 & 25.00 \\
\hline 45 & Kassakou & 4 & 3 & 0 & 0 & 1 & 0 & 1 & 25.00 \\
\hline 46 & Kaki Koka & 4 & 2 & 1 & 0 & 1 & 0 & 1 & 25.00 \\
\hline 47 & Koussin-Lélé & 4 & 2 & 0 & 0 & 2 & 1 & 1 & 25.00 \\
\hline 48 & Dovi-Zounnou & 2 & 1 & 0 & 0 & 1 & 1 & 0 & 0.00 \\
\hline 49 & Dévé & 2 & 1 & 0 & 0 & 1 & 1 & 0 & 0.00 \\
\hline 50 & Gativé & 2 & 1 & 1 & 0 & 0 & 0 & 0 & 0.00 \\
\hline 51 & Gouti & 2 & 1 & 1 & 0 & 0 & 0 & 0 & 0.00 \\
\hline 52 & Houéda & 2 & 1 & 1 & 0 & 0 & 0 & 0 & 0.00 \\
\hline 53 & Mitro & 2 & 1 & 1 & 0 & 0 & 0 & 0 & 0.00 \\
\hline 54 & Hêtin- Sota & 2 & 1 & 1 & 0 & 0 & 0 & 0 & 0.00 \\
\hline 55 & Dogbo - Kounotcho & 2 & 1 & 0 & 1 & 0 & 0 & 0 & 0.00 \\
\hline MEAN & & 4 & 2 & $\mathbf{0}$ & $\mathbf{0}$ & 2 & $\mathbf{0}$ & 2 & 41 \\
\hline
\end{tabular}

TNV, Total number of varieties; $\mathrm{H}+\mathrm{A}+$, Many households and large area; $\mathrm{H}+\mathrm{A}-$, Many households and small area; $\mathrm{H}-\mathrm{A}+$, Few households and large area; H-A-, Few households and small area; NNIV, number of newly introduced varieties; NVD, number of varieties in disappearance; RLD, rate of loss of diversity.

The Schannon diversity index $(\mathrm{H})$ calculated is 5.62 and shows that a high varietal diversity exists in the study area but unevenly distributed. In fact, it is low in zones I, III, VI, VII and VIII, and average in zones II, IV and $\mathrm{V}$ (Table 3). The varieties recorded in the study area have a cycle ranging from 2 to 5 months. Subject to synonymy, varieties with a 3 month cycle are the most numerous and account for $59.79 \%$. Varieties with cycles between 3.5 months and 5 months and those from 2 to 2.5 months represent $34.01 \%$ and $6.18 \%$ respectively
(Fig. 2). There are $81.62 \%$ of traditional varieties, the most widespread being Gambiaka and $18.18 \%$ of improved varieties, the most widespread of which is IR 841. These varieties are mainly cultivated in lowlands $(93.81 \%)$. However, there are $5.31 \%$ of strict rainfed rice varieties and about $0.88 \%$ grown both in the lowland and on the upland. From the 95 varieties listed, only two (Mongni Kpika and Mouri Kplinnou) are Oryza glaberrima is $2.06 \%$. The remaining $97.94 \%$ are Oryza sativa. 
Table 3. Diversity, distribution, extent and rate of loss of varieties per agro-ecological zone

\begin{tabular}{|c|c|c|c|c|c|c|c|c|c|}
\hline \multirow{2}{*}{ Agro-ecological zones } & \multirow{2}{*}{ NTV } & \multicolumn{4}{|c|}{ Distribution and extent } & \multirow{2}{*}{ NNIV } & \multirow{2}{*}{ NVD } & \multirow{2}{*}{$\operatorname{RLD}(\%)$} & \multirow{2}{*}{ SI } \\
\hline & & $\mathbf{H}+\mathbf{A}+$ & $\mathrm{H}+\mathrm{A}-$ & H-A+ & H-A- & & & & \\
\hline Zone II & 40 & 15 & 3 & 0 & 22 & 2 & 20 & 50.00 & 3.03 \\
\hline Zone V & 46 & 18 & 3 & 1 & 24 & 2 & 22 & 47.83 & 3.57 \\
\hline Zone IV & 50 & 20 & 2 & 0 & 28 & 5 & 23 & 46.00 & 3.21 \\
\hline Zone III & 22 & 10 & 0 & 1 & 11 & 1 & 10 & 45.45 & 2.52 \\
\hline Zone VII & 11 & 5 & 0 & 1 & 5 & 0 & 5 & 45.45 & 1.94 \\
\hline Zone I & 11 & 6 & 2 & 0 & 3 & 0 & 3 & 27.27 & 0.85 \\
\hline Zone VI & 12 & 6 & 0 & 0 & 6 & 3 & 3 & 25.00 & 2.25 \\
\hline Zone VIII & 12 & 6 & 5 & 0 & 1 & 0 & 1 & 8.33 & 2.58 \\
\hline Mean & 26 & 11 & 2 & $\mathbf{0}$ & 13 & 2 & 11 & 36.92 & 2.49 \\
\hline
\end{tabular}

SI, Shannon Index.

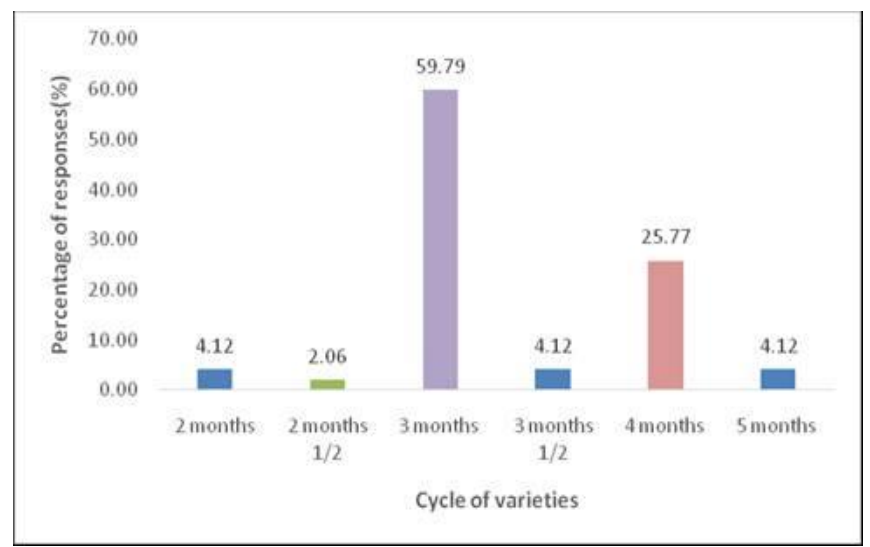

Fig. 2: Duration of the cycle of rice varieties grown in Benin.

Analysis of the distribution and extent of the listed varieties (Table 4) shows that 40 varieties of rice are produced by many households and over large areas. These varieties are those perceived by the producers as having good agronomic, culinary and technological performances such as high productivity, high market value, good organoleptic quality, and good resistance to drought (IR 841, Béris 21, Tchewegena and Chamarica). Eleven varieties are cultivated by many households over a small area. These varieties exhibit good yield but long cycle and poor market value (Grand Djimbo, De Gaulle, Monlou takpitô).

Three varieties are cultivated by few households and over a large area. According to the farmers, these varieties have good market value but are susceptible to weeds. Finally, 60 varieties are cultivated by few households and over small areas (Table 4). According to the producers, these varieties have many weaknesses such as susceptibility to flood; low yield; susceptibility to lodging and poor organoleptic quality.
In villages where some varieties have disappeared (Table 5), the rate of loss of varieties varies from $25 \%$ (Koussin-Lele, Kaki Koka, Madecali) to 75\% (Adjantè) with an average of $41 \%$ (Table 3 ). This also varies from one agro-ecological zone to another. It is higher in zone II (50\%) and lower in zone VIII (8.33\%) (Table 3).

The causes of loss of varietal diversity are manifold and can be grouped into three categories which are agronomic (79.49\% of responses), culinary and technological (13.33\% of responses) and economic ( $7.18 \%$ of responses). Among the agronomic reasons, the most important ones are the introduction of new high-performance varieties (38.97\% of responses), the long cycle (17.44\% of responses) and low productivity ( $9.23 \%$ of responses). Poor organoleptic quality $(6.15 \%$ responses) and poor grain quality $(4.60 \%)$ are the main culinary and technological reasons for abandoning varieties in the study area. Finally, poor market value ( $7.18 \%$ of responses) is the only economic reason cited by producers (Table 5 ).

In the study area varieties encountered do not have the same distribution, or the same extent. Nérica-L-20 for instance grown in Awokpa (Zè) and Domè (Zogbodomey) by many households and over a large area is cultivated in Dovi- Zounnou (Zangnanado) and Toffo-Center (Atlantic) few households and small area (Table 4). IR 841 is widely distributed and occurs in thirty-six (36) villages surveyed out of 55. In all the villages where this variety was found, it is present in many households and is grown on large area (Table 4). On the other hand, certain varieties such as Imon ouan, Imon pia, Imondobi, Imonhan Ipèyi are found only in one village (Table 4). 
Table 4. Vernacular name, cycle, distribution and extent of selected rice varieties.

\begin{tabular}{|c|c|c|}
\hline $\mathbf{N}^{\circ}$ & Vernacular name & Cycle (Day), Village, distribution and extent \\
\hline 1 & Adini 11 & (110), Founougo (+-) \\
\hline 2 & Ansinè Angbiya & (120), Sinawongourou (--) \\
\hline 3 & Batoun mongni & (90), Sékéré (--); Gounmori (--), Founougo (--) \\
\hline 4 & Béris 21 & (110), Founougo (++); Adjantè (--) \\
\hline 5 & BL 19 & (90), Kassakou (++); Kaki Koka (++); Kondo (--); Dikoumini (--); Koussin-Lélé (--) \\
\hline 6 & Burkina & (90), Founougo (--) \\
\hline 7 & Carder & (90), Bétérou (+-); Sérékali (++); Koni (++) \\
\hline 8 & Carder souan & (90), Sam (+-) \\
\hline 9 & Chamarica & (90), Tapoga $(++)$ \\
\hline 10 & Consommable (IR841) & (90), Dogbo-Kounotcho (++) \\
\hline 11 & Danzaria & (90), Madécali (--) \\
\hline 12 & De Gaulle & (120), Tomboutou (--); Gounmori (--); Sinawongourou (--); Fô-Bouré (--); Madjavi (+-) \\
\hline 13 & Gambiaka & $\begin{array}{l}\text { (120), Alafiarou (--); Kaki Koka (++); Bétérou (--); Koni (--); Totorou (--); Toubougnini (-- } \\
\text { ); Tapoga (--); Pègou (--); Dikoumini (--); Dipokor } 1(++) \text {; Gobé (--); Atokolibé (--); } \\
\text { Adjantè (--); Domè (--); Domè (--); Wèrè (--) }\end{array}$ \\
\hline 14 & Gambiaka laguê & (90), Kondo $(++)$ \\
\hline 15 & Gavioga & (120), Monkpa (--) \\
\hline 16 & Gazéré & (90), Madécali (++) \\
\hline 17 & Gbengua & (90), Wèrè (++) \\
\hline 18 & Grand Djimbo & (90), Madécali (+-) \\
\hline 19 & Guibitounga & (120), Kassakou (--); Wèrè (--) \\
\hline 20 & Houmonhanni & (75), Totorou (--) \\
\hline 21 & Imon Boka & (120), Dipokor $1(++)$ \\
\hline 22 & Imon ouan & (90), Alafiarou (--) \\
\hline 23 & Imon pia & (120), Alafiarou (--); Dipokor 1 (++) \\
\hline 24 & Imondobi & (90), Tapoga (--) \\
\hline 25 & Imonhan Ipèyi & (75), Dogo (++) \\
\hline 26 & Imonhan Iwonnin & (90), Dogo (++) \\
\hline 27 & Imonni & (120), Alafiarou (--) \\
\hline 28 & Imouri Doki & (120), Dikoumini (--) \\
\hline 29 & Inaris & (90), Sinawongourou (--); Sam (+-) \\
\hline 30 & IR 841 & $\begin{array}{l}\text { (90), Tomboutou (++); Kassakou (++); Alafiarou (++); Kaki Koka (--); Toubougnini (++); } \\
\text { Kondo (++); Pègou (++); Dikoumini (++); Tchetti (++); Monkpa (++); Gobé (++); } \\
\text { Atokolibé (++); Adjantè (++); Koussin-Lélé (++); Dovi- Zounnou (++); Domè (--); Dévé } \\
(++) \text {; Tandji (++); Houinga-Houégbé (--); Hokpamè (++); Gativé (++); Gouti (++); Houéda } \\
(++) \text {; Mitro (++); Toffo-Centre (++); Awokpa (--); Madécali (++); Founougo (++); } \\
\text { Sinawongourou (++); Bétérou (++); Sérékali (++); Sèmèrè (--); Kpassabega (++); Allan } \\
(++) \text {; Kodowari (++); Sowé (++);Hêtin-Sota (++) }\end{array}$ \\
\hline 31 & Issomonhan & (90), Dipokor $1(--)$ \\
\hline 32 & Jasmine & (90), Tchetti (--) \\
\hline 33 & Koitéguizé & (90), Madécali (--) \\
\hline 34 & Koumouloukonga & (90), Pègou (--) \\
\hline 35 & Koumouloumonga & (90), Pègou (+-) \\
\hline 36 & Kri Ita & (90), Kpassabega (++) \\
\hline 37 & L 20 & (90), Kassakou (++); Tandji (--); Gativé (--); Founougo (--) \\
\hline 38 & L19 & (120), Founougo (--) \\
\hline 39 & lèbèlèbè & (120), Kpassabega (--) \\
\hline 40 & Lobolobo & (135), Sèmèrè (++); Kodowari (--) \\
\hline 41 & Mayada & (90), Sérékali (--) \\
\hline 42 & Moépian & (120), Lougou (--); Piami (--) \\
\hline 43 & Moépoua & (120), Lougou (++); Piami (++) \\
\hline 44 & Mongni douab lack & (90), Toubougnini (--) \\
\hline
\end{tabular}




\begin{tabular}{|c|c|c|}
\hline $\mathbf{N}^{\circ}$ & Vernacular name & Cycle (Day), Village, distribution and extent \\
\hline 45 & Mongni gbènou & (120), Sékéré (++); Wara (--) \\
\hline 46 & Mongni Koukourikê & (90), Kondo (--) \\
\hline 47 & Mongni Kpika & (90), Sékéré (-+) \\
\hline 48 & Mongni Pam pam & (120), Kondo (--) \\
\hline 49 & Mongni Poé Lakê & (90), Kondo (--) \\
\hline 50 & Mongni souannou & (90), Sékéré (--) \\
\hline 51 & Monkoukou & (90), Bétérou (--) \\
\hline 52 & Monlou takpitô & (90), Tandji (--) \\
\hline 53 & Monniti & (120), N'Dahonta (--) \\
\hline 54 & Monri Bossérou & (90), Fô-Bouré (++) \\
\hline 55 & Monwassou & (90), Bétérou (--) \\
\hline 56 & Mouri Kplinnou & (120), Fô-Tancé (--) \\
\hline 57 & Mouri Souri Inè & (120), Fô-Tancé (++) \\
\hline 58 & Mouri Souri Ita & (90), Fô-Tancé (--) \\
\hline 59 & Mri monri & (90), Kpassabega (--) \\
\hline 60 & Nadréki & (90), Pègou (--) \\
\hline 61 & Namonhan Tadana & (90), Dipokor 1 (--) \\
\hline 62 & Nérica & (90), N'Dahonta (+-) \\
\hline 63 & Nérica 14 & (90), Kaki Koka (+-); Domè (++); Dévé (--); Houinga-Houégbé (++); Hokpamè (--) \\
\hline 64 & Nérica 2 & (90), Toubougnini (--) \\
\hline 65 & Nérica 20 & $\begin{array}{l}\text { (90), Toubougnini (++); Kondo (++); Pègou (++); Koussin-Lélé (--); Dovi- Zounnou (--); } \\
\text { Domè (++); Gouti (+-); Houéda (+-); Mitro (+-); Toffo-Centre (--); Awokpa (++); Allan (-- } \\
\text { ); Hêtin-Sota (+-) }\end{array}$ \\
\hline 66 & Nérica 4 & (110), Founougo (--); Pègou (++); Dogo (--) \\
\hline 67 & Olotchoumédji 1 (Kogbèdè) & (60), Sowé (--) \\
\hline 68 & Olotchoumédji 2 (Sanglola) & (60), Sowé $(++)$ \\
\hline 69 & Orou kpehinte (IRAT 127) & (90), Sam (--) \\
\hline 70 & Orou Mississi & (90), Gounmori (++) \\
\hline 71 & Orouwiro (riz sauvage) & (60), Wara (--) \\
\hline 72 & Owiro & (60), Sam (--) \\
\hline 73 & Petit Djimbo & (90), Madécali (+-) \\
\hline 74 & Ponnin & (90), Fô-Bouré (--) \\
\hline 75 & Pouéssoir (Béris 21) & (110), Dikoumini (++) \\
\hline 76 & Précoce & (90), Tomboutou (++); Bétérou (-+); Totorou (--) \\
\hline 77 & Projet (BL19) & (90), Dipokor $1(--)$ \\
\hline 78 & R 8 & (120), Madécali (++); Bétérou (--); Totorou (++) \\
\hline 79 & Riz de montagne & (90), Dikoumini (--) \\
\hline 80 & Semence (Nérica 20) & (90), Dogbo-Kounotcho (-+) \\
\hline 81 & Souhannin & (120), Madjavi (++) \\
\hline 82 & Souhatôn 1 & (150), Madjavi (++) \\
\hline 83 & Souhatôn 2 & (150), Madjavi (++) \\
\hline 84 & Souhatôn 3 & (150), Madjavi (--) \\
\hline 85 & Souhatôn 4 & (150), Madjavi (--) \\
\hline 86 & Soulé yorou & (90), Wèrè (++) \\
\hline 87 & Tchèwèrèga & (90), N'Dahonta (++) \\
\hline 88 & Tchinhin & (90), Koussin-Lélé (++) \\
\hline 89 & Tchroéitama & (120), Dendougou (--) \\
\hline 90 & Tchroinès & (120), Dendougou (--) \\
\hline 91 & Tchroinesma & (90), Dendougou $(++)$ \\
\hline 92 & Tissu & $(120)$, Totorou $(++)$ \\
\hline 93 & WAB 32 & (120), Toubougnini (++); Kondo (--); Atokolibé (--); Adjantè (--) \\
\hline 94 & Yayi Boni & (90), Sinawongourou (++); Wèrè (++); Wara (++) \\
\hline 95 & Yayi Boni Kpika & (90), Sam (++) \\
\hline
\end{tabular}


Table 5. Main reasons for loss of varietal diversity in the study area

\begin{tabular}{lll}
\hline Categories of reasons & Different types & Percentage of responses (\%) \\
\hline Agronomy (79.49\%) & Introduction of new high-performance varieties & 38.97 \\
& Long Cycle & 17.44 \\
& Low productivity & 9.23 \\
& Easy ginning & 6.15 \\
& Strong earliness (Spell in the period of rain and rot quickly) & 4.10 \\
& Strong water requirement & 1.54 \\
& High sensitivity to lodging & 1.03 \\
& Irritability in body contact & 1.03 \\
Culinary and & Poor organoleptic quality (pasty, bad taste) & 6.15 \\
technological (13.33\%) & Quality of grains (Red Grain, much breaking, Grain too short) & 5.13 \\
& Low productivity when cooking (Does not swell well) & 2.05 \\
Economic (7.18\%) & Poor market value & 7,18 \\
\hline
\end{tabular}

Structuration of the diversity on the basis of
agronomic, culinary and technological characteristics

Variation of the agronomic, culinary and technological characteristics between different varieties of rice of Benin that producers use most often to describe their varieties in terms of performance was assessed through a cluster analysis. The 95 names of rice obtained subject to synonymy have been grouped into 49 units (U1 to U49, Table 6, Fig. 3) and 4 different groups (G1 to G4, Fig. 3).

- G1 consists of 21 units (U1 to U21) and $57.89 \%$ of the varieties. It contains highly productive varieties that are tolerant to drought, lodging, and blight but susceptible to birds. They have a good taste, high cooking efficiency with a low breaking rate.

- G2 is composed of 5 units (U22 to U26) and $5.26 \%$ of the varieties. It is the group of varieties that are not very productive, tolerant to drought and lodging but susceptible to blast and birds. They have a good taste with a high break rate and a low cooking yield.

- G3 contains 15 units (U27 to U41) and $26.32 \%$ of the varieties. This group is that of productive varieties, very susceptible to drought, lodging and blast but with good taste and good cooking yield. They are sensitive to birds with a very high breaking rate.

- G4 contains 8 units (U42 to U49) and $10.53 \%$ of the varieties. This group includes productive varieties that are susceptible to drought and lodging but are very tolerant to blast and birds. They have a bad taste, a low cooking yield but a low breaking rate.
In order to better identify the most discriminating variables, a discriminant factorial analysis through the $\lambda$ Wilk test was performed from the classes obtained with the HAC. This analysis shows that only variables such as drought tolerance, lodging tolerance, blast tolerance, taste, cooking yield, breaking rate allow a clear distinction of varieties in four classes.

\section{Socio-cultural determinants of rice diversity at household level}

The results of the multiple logistic regression carried out to model the relationship between the varietal diversity of rice maintained per household and socio-cultural characteristics (sex, age, educational attainment, marital status, religion, year of experience, household size, Valid and belonging to an association) are presented in Table 7. The results of the saturated model, taking into account all the variables and their interactions, made it possible to identify the variables that determine the maintenance of the varietal diversity of the Beninese rice farmers. These are age $(p<0.05)$, size of the household $(p<0.05)$ and valid arm $(p<0.001)$.

\section{Farmers' preferences or selection criteria}

Within the existing diversity, 16 farmers' varietal preference criteria including 01 economic (high market value), 8 culinary and technological and 7 agronomic were identified across the villages (Table 8). Among these, high productivity ( $31.87 \%$ of responses) and early cycle cycles (18.89\% of responses), good tillering, tolerance to weeds, flavor, aroma more important. Although the importance of the criteria varies troughout agro-ecological zones, the general trend is the same across all the agro-ecological zones considered with some exceptions (Table 8). 
Table 6. Characteristics of rice units identified on the basis of agronomic, culinary and technological identities.

\begin{tabular}{|c|c|c|c|c|c|c|c|c|c|c|c|c|c|c|}
\hline \multirow{2}{*}{ Group } & \multirow{2}{*}{ Unit } & \multirow{2}{*}{$\begin{array}{l}\text { No. of } \\
\text { varieties }\end{array}$} & \multirow{2}{*}{ List of varieties } & \multicolumn{11}{|c|}{ Agronomic, culinary and technological characteristics } \\
\hline & & & & Pr & Cy (M) & Td & Lt & $\mathbf{T p}$ & Fri & $\mathbf{S b}$ & Ta & CoY & Fc & Br \\
\hline \multirow[t]{21}{*}{1} & U1 & 6 & $\begin{array}{l}\text { R8; Mongnigbènou; } \\
\text { MouriKplinnou; MouriSouriInè; } \\
\text { Tchroéitama; Tchroinès }\end{array}$ & $\operatorname{Pr}(\mathrm{S})$ & 4 & $\mathrm{Td}(\mathrm{B})$ & $\mathrm{Lt}(\mathrm{G})$ & $\mathrm{Tp}(\mathrm{G})$ & Fri $(G)$ & $\mathrm{Sb}(\mathrm{Se})$ & $\mathrm{Ta}(\mathrm{G})$ & CoY (I) & $\mathrm{Fc}(\mathrm{F})$ & $\mathrm{Br}(\mathrm{L})$ \\
\hline & $\mathrm{U} 2$ & 2 & Moépian; Monniti & $\operatorname{Pr}(\mathrm{S})$ & 4 & $\mathrm{Td}(\mathrm{B})$ & $\mathrm{Lt}(\mathrm{G})$ & $\mathrm{Tp}(\mathrm{G})$ & Fri $(G)$ & $\mathrm{Sb}(\mathrm{Se})$ & $\mathrm{Ta}(\mathrm{G})$ & $\operatorname{CoY}(\mathrm{I})$ & $\mathrm{Fc}(\mathrm{Sl})$ & $\mathrm{Br}(\mathrm{L})$ \\
\hline & $\mathrm{U} 3$ & 2 & Sanglola; Kogbèdè & $\operatorname{Pr}(\mathrm{S})$ & 2 & $\mathrm{Td}(\mathrm{B})$ & $\mathrm{Lt}(\mathrm{G})$ & $\mathrm{Tp}(\mathrm{G})$ & Fri $(G)$ & $\mathrm{Sb}(\mathrm{Se})$ & $\mathrm{Ta}(\mathrm{G})$ & $\operatorname{CoY}(\mathrm{I})$ & $\mathrm{Fc}(\mathrm{F})$ & $\mathrm{Br}(\mathrm{L})$ \\
\hline & $\mathrm{U} 4$ & 6 & $\begin{array}{l}\text { Gazéré; OrouMississi; Gbengua; } \\
\text { Souléyorou; MouriSouriIta; } \\
\text { Jasmine }\end{array}$ & $\operatorname{Pr}(\mathrm{S})$ & 3 & $\mathrm{Td}(\mathrm{B})$ & $\mathrm{Lt}(\mathrm{G})$ & $\mathrm{Tp}(\mathrm{G})$ & Fri $(G)$ & $\mathrm{Sb}(\mathrm{Se})$ & $\mathrm{Ta}(\mathrm{G})$ & $\operatorname{CoY}(\mathrm{I})$ & $\mathrm{Fc}(\mathrm{F})$ & $\mathrm{Br}(\mathrm{L})$ \\
\hline & U5 & 2 & L19; WAB32 & $\operatorname{Pr}(\mathrm{S})$ & 4 & $\mathrm{Td}(\mathrm{G})$ & $\mathrm{Lt}(\mathrm{G})$ & $\mathrm{Tp}(\mathrm{G})$ & Fri $(\mathrm{G})$ & $\mathrm{Sb}(\mathrm{Se})$ & $\mathrm{Ta}(\mathrm{G})$ & $\operatorname{CoY}(\mathrm{I})$ & $\mathrm{Fc}(\mathrm{F})$ & $\mathrm{Br}(\mathrm{L})$ \\
\hline & U6 & 3 & Béris21; Nérica4; Pouéssoir & $\operatorname{Pr}(\mathrm{S})$ & 3.5 & $\mathrm{Td}(\mathrm{G})$ & $\mathrm{Lt}(\mathrm{G})$ & $\operatorname{Tp}(\mathrm{G})$ & Fri $(\mathrm{G})$ & $\mathrm{Sb}(\mathrm{Se})$ & $\mathrm{Ta}(\mathrm{G})$ & $\operatorname{CoY}(\mathrm{I})$ & $\mathrm{Fc}(\mathrm{F})$ & $\mathrm{Br}(\mathrm{L})$ \\
\hline & $\mathrm{U} 7$ & 9 & $\begin{array}{l}\text { Précoce; L20; BL19; } \\
\text { Koumouloumonga; Projet; KriIta; } \\
\text { NéricaL20; Monloutakpitô; } \\
\text { Semence }\end{array}$ & $\operatorname{Pr}(S)$ & 3 & $\mathrm{Td}(\mathrm{G})$ & $\mathrm{Lt}(\mathrm{G})$ & $\operatorname{Tp}(\mathrm{G})$ & Fri $(G)$ & $\mathrm{Sb}(\mathrm{Se})$ & $\mathrm{Ta}(\mathrm{G})$ & $\operatorname{CoY}(\mathrm{I})$ & $\mathrm{Fc}(\mathrm{F})$ & $\mathrm{Br}(\mathrm{L})$ \\
\hline & U8 & 6 & $\begin{array}{l}\text { Cardersouan; Imonouan; } \\
\text { NéricaL14; Carder; Tchèwèrèga; } \\
\text { Issomonhan }\end{array}$ & $\operatorname{Pr}(\mathrm{S})$ & 3 & $\mathrm{Td}(\mathrm{G})$ & $\mathrm{Lt}(\mathrm{G})$ & $\mathrm{Tp}(\mathrm{G})$ & Fri (B) & $\mathrm{Sb}(\mathrm{Se})$ & $\mathrm{Ta}(\mathrm{G})$ & $\operatorname{CoY}(\mathrm{I})$ & $\mathrm{Fc}(\mathrm{F})$ & $\mathrm{Br}(\mathrm{L})$ \\
\hline & U9 & 1 & Adini11 & $\operatorname{Pr}(\mathrm{S})$ & 3.5 & $\mathrm{Td}(\mathrm{G})$ & $\mathrm{Lt}(\mathrm{G})$ & $\mathrm{Tp}(\mathrm{G})$ & Fri (B) & $\mathrm{Sb}(\mathrm{Se})$ & $\mathrm{Ta}(\mathrm{G})$ & $\operatorname{CoY}(\mathrm{I})$ & $\mathrm{Fc}(\mathrm{F})$ & $\mathrm{Br}(\mathrm{L})$ \\
\hline & U10 & 4 & $\begin{array}{l}\text { GrandDjimbo; Monwassou; } \\
\text { Monkoukou; Tchroinesma }\end{array}$ & $\operatorname{Pr}(\mathrm{S})$ & 3 & $\mathrm{Td}(\mathrm{B})$ & $\mathrm{Lt}(\mathrm{G})$ & $\operatorname{Tp}(\mathrm{G})$ & Fri (B) & $\mathrm{Sb}(\mathrm{Se})$ & $\mathrm{Ta}(\mathrm{G})$ & CoY (I) & $\mathrm{Fc}(\mathrm{F})$ & $\mathrm{Br}(\mathrm{L})$ \\
\hline & U11 & 1 & ImouriDoki & $\operatorname{Pr}(\mathrm{S})$ & 4 & $\mathrm{Td}(\mathrm{B})$ & $\mathrm{Lt}(\mathrm{G})$ & $\mathrm{Tp}(\mathrm{G})$ & Fri $(\mathrm{G})$ & $\mathrm{Sb}(\mathrm{Se})$ & $\mathrm{Ta}(\mathrm{G})$ & CoY (Dns) & $\mathrm{Fc}(\mathrm{F})$ & $\mathrm{Br}(\mathrm{L})$ \\
\hline & U12 & 1 & Boukina & $\operatorname{Pr}(\mathrm{S})$ & 3 & $\mathrm{Td}(\mathrm{B})$ & $\mathrm{Lt}(\mathrm{G})$ & $\mathrm{Tp}(\mathrm{G})$ & Fri $(G)$ & $\mathrm{Sb}(\mathrm{Se})$ & $\mathrm{Ta}(\mathrm{G})$ & CoY (Dns) & $\mathrm{Fc}(\mathrm{F})$ & $\mathrm{Br}(\mathrm{L})$ \\
\hline & U13 & 1 & Nadréki & $\operatorname{Pr}(\mathrm{S})$ & 3 & $\mathrm{Td}(\mathrm{G})$ & $\mathrm{Lt}(\mathrm{G})$ & $\mathrm{Tp}(\mathrm{G})$ & Fri $(G)$ & $\mathrm{Sb}(\mathrm{Se})$ & $\mathrm{Ta}(\mathrm{G})$ & CoY (Dns) & $\mathrm{Fc}(\mathrm{F})$ & $\mathrm{Br}(\mathrm{L})$ \\
\hline & U14 & 1 & Tissu & $\operatorname{Pr}(\mathrm{S})$ & 4 & $\mathrm{Td}(\mathrm{B})$ & $\mathrm{Lt}(\mathrm{G})$ & $\mathrm{Tp}(\mathrm{G})$ & Fri (B) & $\mathrm{Sb}(\mathrm{Se})$ & $\mathrm{Ta}(\mathrm{G})$ & CoY (Dns) & $\mathrm{Fc}(\mathrm{F})$ & $\mathrm{Br}(\mathrm{L})$ \\
\hline & U15 & 1 & Mrimonri & $\operatorname{Pr}(\mathrm{S})$ & 3 & $\mathrm{Td}(\mathrm{B})$ & $\mathrm{Lt}(\mathrm{G})$ & $\mathrm{Tp}(\mathrm{B})$ & Fri $(G)$ & $\mathrm{Sb}(\mathrm{Se})$ & $\mathrm{Ta}(\mathrm{G})$ & CoY (Dns) & $\mathrm{Fc}(\mathrm{F})$ & $\mathrm{Br}(\mathrm{L})$ \\
\hline & U16 & 1 & Rizdemontagne & $\operatorname{Pr}(\mathrm{S})$ & 3 & $\mathrm{Td}(\mathrm{G})$ & $\mathrm{Lt}(\mathrm{G})$ & $\mathrm{Tp}(\mathrm{G})$ & Fri $(G)$ & $\mathrm{Sb}(\mathrm{Se})$ & $\mathrm{Ta}(\mathrm{G})$ & $\operatorname{CoY}(\mathrm{I})$ & $\mathrm{Fc}(\mathrm{Sl})$ & $\mathrm{Br}(\mathrm{L})$ \\
\hline & U17 & 1 & MongniPoéLakê & $\operatorname{Pr}(\mathrm{S})$ & 3 & $\mathrm{Td}(\mathrm{G})$ & $\mathrm{Lt}(\mathrm{G})$ & $\mathrm{Tp}(\mathrm{G})$ & Fri $(G)$ & $\mathrm{Sb}(\mathrm{Se})$ & $\mathrm{Ta}(\mathrm{G})$ & $\operatorname{CoY}(\mathrm{I})$ & $\mathrm{Fc}(\mathrm{Sl})$ & $\mathrm{Br}(\mathrm{H})$ \\
\hline & U18 & 1 & OrouKpéhinté & $\operatorname{Pr}(\mathrm{S})$ & 3 & $\mathrm{Td}(\mathrm{G})$ & $\mathrm{Lt}(\mathrm{B})$ & $\mathrm{Tp}(\mathrm{G})$ & Fri (B) & $\mathrm{Sb}(\mathrm{Se})$ & $\mathrm{Ta}(\mathrm{G})$ & $\operatorname{CoY}(\mathrm{I})$ & $\mathrm{Fc}(\mathrm{Sl})$ & $\mathrm{Br}(\mathrm{H})$ \\
\hline & U19 & 4 & $\begin{array}{l}\text { IR841; YayiBoni; YayiBoniKpika; } \\
\text { Consommable; }\end{array}$ & $\operatorname{Pr}(S)$ & 3 & $\mathrm{Td}(\mathrm{G})$ & $\mathrm{Lt}(\mathrm{G})$ & $\mathrm{Tp}(\mathrm{G})$ & Fri $(\mathrm{G})$ & $\mathrm{Sb}(\mathrm{Se})$ & $\mathrm{Ta}(\mathrm{G})$ & $\operatorname{CoY}(\mathrm{I})$ & $\mathrm{Fc}(\mathrm{F})$ & $\mathrm{Br}(\mathrm{H})$ \\
\hline & $\mathrm{U} 20$ & 1 & ImonhanIpèyi & $\operatorname{Pr}(\mathrm{S})$ & 2.5 & $\mathrm{Td}(\mathrm{B})$ & $\mathrm{Lt}(\mathrm{G})$ & $\mathrm{Tp}(\mathrm{G})$ & Fri $(G)$ & $\mathrm{Sb}(\mathrm{Se})$ & $\mathrm{Ta}(\mathrm{G})$ & $\operatorname{CoY}(\mathrm{I})$ & $\mathrm{Fc}(\mathrm{F})$ & $\mathrm{Br}(\mathrm{H})$ \\
\hline & $\mathrm{U} 21$ & 1 & Koumouloukonga & $\operatorname{Pr}(\mathrm{S})$ & 3 & $\mathrm{Td}(\mathrm{G})$ & $\mathrm{Lt}(\mathrm{G})$ & $\mathrm{Tp}(\mathrm{G})$ & Fri $(G)$ & $\mathrm{Sb}(\mathrm{Se})$ & $\mathrm{Ta}(\mathrm{G})$ & CoY (Dns) & $\mathrm{Fc}(\mathrm{F})$ & $\mathrm{Br}(\mathrm{H})$ \\
\hline
\end{tabular}




\begin{tabular}{|c|c|c|c|c|c|c|c|c|c|c|c|c|c|c|}
\hline \multirow{2}{*}{ Group } & \multirow{2}{*}{ Unit } & \multirow{2}{*}{$\begin{array}{l}\text { No. of } \\
\text { varieties }\end{array}$} & \multirow{2}{*}{ List of varieties } & \multicolumn{11}{|c|}{ Agronomic, culinary and technological characteristics } \\
\hline & & & & Pr & Cy (M) & Td & Lt & $\mathbf{T p}$ & Fri & Sb & Ta & CoY & Fc & Br \\
\hline \multirow[t]{5}{*}{2} & $\mathrm{U} 22$ & 1 & MongniKoukourikê & $\operatorname{Pr}(\mathrm{L})$ & 3 & $\mathrm{Td}(\mathrm{G})$ & $\mathrm{Lt}(\mathrm{G})$ & $\mathrm{Tp}(\mathrm{G})$ & Fri $(\mathrm{G})$ & $\mathrm{Sb}(\mathrm{Se})$ & $\mathrm{Ta}(\mathrm{G})$ & CoY (Dns) & $\mathrm{Fc}(\mathrm{F})$ & $\mathrm{Br}(\mathrm{H})$ \\
\hline & $\mathrm{U} 23$ & 1 & Batounmongni & $\operatorname{Pr}(\mathrm{L})$ & 3 & $\mathrm{Td}(\mathrm{G})$ & $\mathrm{Lt}(\mathrm{B})$ & $\mathrm{Tp}(\mathrm{B})$ & Fri $(\mathrm{G})$ & $\mathrm{Sb}(\mathrm{Se})$ & $\mathrm{Ta}(\mathrm{G})$ & $\operatorname{CoY}(\mathrm{I})$ & $\mathrm{Fc}(\mathrm{Sl})$ & $\mathrm{Br}(\mathrm{H})$ \\
\hline & U24 & 1 & Mongnidouablack & $\operatorname{Pr}(\mathrm{L})$ & 3 & $\mathrm{Td}(\mathrm{B})$ & $\mathrm{Lt}(\mathrm{G})$ & $\mathrm{Tp}(\mathrm{G})$ & Fri (B) & $\mathrm{Sb}(\mathrm{Se})$ & $\mathrm{Ta}(\mathrm{G})$ & $\operatorname{CoY}(\mathrm{I})$ & $\mathrm{Fc}(\mathrm{F})$ & $\mathrm{Br}(\mathrm{L})$ \\
\hline & $\mathrm{U} 25$ & 1 & PetitDjimbo & $\operatorname{Pr}(\mathrm{L})$ & 3 & $\mathrm{Td}(\mathrm{G})$ & $\mathrm{Lt}(\mathrm{G})$ & $\operatorname{Tp}(\mathrm{G})$ & Fri $(\mathrm{G})$ & $\mathrm{Sb}(\mathrm{Se})$ & $\mathrm{Ta}(\mathrm{G})$ & $\operatorname{CoY}(\mathrm{I})$ & $\mathrm{Fc}(\mathrm{F})$ & $\mathrm{Br}(\mathrm{L})$ \\
\hline & U26 & 1 & Danzaria & $\operatorname{Pr}(\mathrm{L})$ & 3 & $\mathrm{Td}(\mathrm{B})$ & $\mathrm{Lt}(\mathrm{G})$ & $\mathrm{Tp}(\mathrm{B})$ & Fri (B) & $\mathrm{Sb}(\mathrm{Se})$ & $\mathrm{Ta}(\mathrm{G})$ & $\operatorname{CoY}(\mathrm{I})$ & $\mathrm{Fc}(\mathrm{F})$ & $\mathrm{Br}(\mathrm{L})$ \\
\hline \multirow[t]{15}{*}{3} & $\mathrm{U} 27$ & 1 & AnsinèAngbiya & $\operatorname{Pr}(S)$ & 4 & $\mathrm{Td}(\mathrm{B})$ & $\mathrm{Lt}(\mathrm{G})$ & $\mathrm{Tp}(\mathrm{B})$ & Fri $(G)$ & $\mathrm{Sb}(\mathrm{Se})$ & $\mathrm{Ta}(\mathrm{G})$ & $\operatorname{CoY}(\mathrm{I})$ & $\mathrm{Fc}(\mathrm{F})$ & $\mathrm{Br}(\mathrm{L})$ \\
\hline & $\mathrm{U} 28$ & 1 & Moépoua & $\operatorname{Pr}(\mathrm{S})$ & 4 & $\mathrm{Td}(\mathrm{B})$ & $\mathrm{Lt}(\mathrm{G})$ & $\mathrm{Tp}(\mathrm{B})$ & Fri (B) & $\mathrm{Sb}(\mathrm{Se})$ & $\mathrm{Ta}(\mathrm{G})$ & $\operatorname{CoY}(\mathrm{I})$ & $\mathrm{Fc}(\mathrm{F})$ & $\mathrm{Br}(\mathrm{L})$ \\
\hline & U29 & 2 & MonriBossérou; Nérica & $\operatorname{Pr}(\mathrm{S})$ & 3 & $\mathrm{Td}(\mathrm{B})$ & $\mathrm{Lt}(\mathrm{G})$ & $\mathrm{Tp}(\mathrm{B})$ & Fri (B) & $\mathrm{Sb}(\mathrm{Se})$ & $\mathrm{Ta}(\mathrm{G})$ & $\operatorname{CoY}(\mathrm{I})$ & $\mathrm{Fc}(\mathrm{F})$ & $\mathrm{Br}(\mathrm{L})$ \\
\hline & U30 & 1 & Houmonhanni & $\operatorname{Pr}(S)$ & 2.5 & $\mathrm{Td}(\mathrm{B})$ & $\mathrm{Lt}(\mathrm{G})$ & $\mathrm{Tp}(\mathrm{B})$ & Fri (B) & $\mathrm{Sb}(\mathrm{Se})$ & $\mathrm{Ta}(\mathrm{G})$ & $\operatorname{CoY}(\mathrm{I})$ & $\mathrm{Fc}(\mathrm{F})$ & $\mathrm{Br}(\mathrm{L})$ \\
\hline & U31 & 2 & Koitéguizé; Chamarica & $\operatorname{Pr}(\mathrm{S})$ & 3 & $\mathrm{Td}(\mathrm{B})$ & $\mathrm{Lt}(\mathrm{B})$ & $\mathrm{Tp}(\mathrm{B})$ & Fri (B) & $\mathrm{Sb}(\mathrm{Se})$ & $\mathrm{Ta}(\mathrm{G})$ & $\operatorname{CoY}(\mathrm{I})$ & $\mathrm{Fc}(\mathrm{F})$ & $\mathrm{Br}(\mathrm{L})$ \\
\hline & U32 & 1 & Gambiakalaguê & $\operatorname{Pr}(\mathrm{S})$ & 3 & $\mathrm{Td}(\mathrm{B})$ & $\mathrm{Lt}(\mathrm{B})$ & $\mathrm{Tp}(\mathrm{B})$ & Fri (B) & $\mathrm{Sb}(\mathrm{Se})$ & $\mathrm{Ta}(\mathrm{G})$ & $\operatorname{CoY}(\mathrm{I})$ & $\mathrm{Fc}(\mathrm{Sl})$ & $\mathrm{Br}(\mathrm{L})$ \\
\hline & U33 & 1 & Gambiaka & $\operatorname{Pr}(S)$ & 4 & $\mathrm{Td}(\mathrm{B})$ & $\mathrm{Lt}(\mathrm{B})$ & $\mathrm{Tp}(\mathrm{B})$ & Fri (B) & $\mathrm{Sb}(\mathrm{Se})$ & $\mathrm{Ta}(\mathrm{G})$ & $\operatorname{CoY}(\mathrm{I})$ & $\mathrm{Fc}(\mathrm{Sl})$ & $\mathrm{Br}(\mathrm{L})$ \\
\hline & U34 & 1 & Imonni & $\operatorname{Pr}(\mathrm{S})$ & 4 & $\mathrm{Td}(\mathrm{B})$ & $\mathrm{Lt}(\mathrm{B})$ & $\operatorname{Tp}(\mathrm{G})$ & Fri (B) & $\mathrm{Sb}(\mathrm{Se})$ & $\mathrm{Ta}(\mathrm{G})$ & $\operatorname{CoY}(\mathrm{I})$ & $\mathrm{Fc}(\mathrm{Sl})$ & $\mathrm{Br}(\mathrm{L})$ \\
\hline & U35 & 2 & Souhatôn3; Souhatôn4 & $\operatorname{Pr}(\mathrm{S})$ & 5 & $\mathrm{Td}(\mathrm{B})$ & $\mathrm{Lt}(\mathrm{B})$ & $\mathrm{Tp}(\mathrm{G})$ & Fri $(\mathrm{G})$ & $\mathrm{Sb}(\mathrm{Se})$ & $\mathrm{Ta}(\mathrm{G})$ & $\operatorname{CoY}(\mathrm{I})$ & $\mathrm{Fc}(\mathrm{F})$ & $\mathrm{Br}(\mathrm{L})$ \\
\hline & U36 & 5 & $\begin{array}{l}\text { Imonpia; Lobolobo; Lébélébé; } \\
\text { Gavioga; Souhannin }\end{array}$ & $\operatorname{Pr}(\mathrm{S})$ & 4 & $\mathrm{Td}(\mathrm{B})$ & $\mathrm{Lt}(\mathrm{B})$ & $\mathrm{Tp}(\mathrm{G})$ & Fri $(G)$ & $\mathrm{Sb}(\mathrm{Se})$ & $\mathrm{Ta}(\mathrm{G})$ & $\operatorname{CoY}(\mathrm{I})$ & $\mathrm{Fc}(\mathrm{F})$ & $\mathrm{Br}(\mathrm{L})$ \\
\hline & U37 & 4 & $\begin{array}{l}\text { MongniKpika; Mayada; } \\
\text { NamonhanTadana; } \\
\text { ImonhanIwonnin }\end{array}$ & $\operatorname{Pr}(\mathrm{S})$ & 3 & $\mathrm{Td}(\mathrm{B})$ & $\mathrm{Lt}(\mathrm{B})$ & $\mathrm{Tp}(\mathrm{G})$ & Fri $(G)$ & $\mathrm{Sb}(\mathrm{Se})$ & $\mathrm{Ta}(\mathrm{G})$ & $\operatorname{CoY}(\mathrm{I})$ & $\mathrm{Fc}(\mathrm{F})$ & $\mathrm{Br}(\mathrm{L})$ \\
\hline & U38 & 1 & ImonBoka & $\operatorname{Pr}(\mathrm{S})$ & 4 & $\mathrm{Td}(\mathrm{G})$ & $\mathrm{Lt}(\mathrm{B})$ & $\operatorname{Tp}(\mathrm{G})$ & Fri (B) & $\mathrm{Sb}(\mathrm{Se})$ & $\mathrm{Ta}(\mathrm{G})$ & $\operatorname{CoY}(\mathrm{I})$ & $\mathrm{Fc}(\mathrm{F})$ & $\mathrm{Br}(\mathrm{L})$ \\
\hline & U39 & 1 & Imondobi & $\operatorname{Pr}(\mathrm{S})$ & 3 & $\mathrm{Td}(\mathrm{G})$ & $\mathrm{Lt}(\mathrm{B})$ & $\operatorname{Tp}(\mathrm{G})$ & Fri (B) & $\mathrm{Sb}(\mathrm{Se})$ & $\mathrm{Ta}(\mathrm{G})$ & $\operatorname{CoY}(\mathrm{I})$ & $\mathrm{Fc}(\mathrm{F})$ & $\mathrm{Br}(\mathrm{L})$ \\
\hline & $\mathrm{U} 40$ & 1 & Tchinhin & $\operatorname{Pr}(\mathrm{S})$ & 3 & $\mathrm{Td}(\mathrm{B})$ & $\mathrm{Lt}(\mathrm{B})$ & $\mathrm{Tp}(\mathrm{G})$ & Fri (B) & $\mathrm{Sb}(\mathrm{Se})$ & $\mathrm{Ta}(\mathrm{G})$ & $\operatorname{CoY}(\mathrm{I})$ & $\mathrm{Fc}(\mathrm{F})$ & $\mathrm{Br}(\mathrm{L})$ \\
\hline & U41 & 1 & De Gaulle & $\operatorname{Pr}(\mathrm{S})$ & 4 & $\mathrm{Td}(\mathrm{B})$ & $\mathrm{Lt}(\mathrm{B})$ & $\operatorname{Tp}(\mathrm{G})$ & Fri (B) & $\mathrm{Sb}(\mathrm{Se})$ & $\mathrm{Ta}(\mathrm{G})$ & $\operatorname{CoY}(\mathrm{I})$ & $\mathrm{Fc}(\mathrm{F})$ & $\mathrm{Br}(\mathrm{L})$ \\
\hline \multirow[t]{8}{*}{4} & U42 & 1 & MongniPampam & $\operatorname{Pr}(\mathrm{S})$ & 4 & $\mathrm{Td}(\mathrm{G})$ & $\mathrm{Lt}(\mathrm{G})$ & $\mathrm{Tp}(\mathrm{G})$ & Fri $(G)$ & $\mathrm{Sb}(\mathrm{Se})$ & $\mathrm{Ta}(\mathrm{B})$ & $\operatorname{CoY}(\mathrm{I})$ & $\mathrm{Fc}(\mathrm{F})$ & $\mathrm{Br}(\mathrm{L})$ \\
\hline & U43 & 1 & Inaris & $\operatorname{Pr}(\mathrm{S})$ & 3 & $\mathrm{Td}(\mathrm{G})$ & $\mathrm{Lt}(\mathrm{G})$ & $\mathrm{Tp}(\mathrm{G})$ & Fri $(\mathrm{G})$ & $\mathrm{Sb}(\mathrm{Se})$ & $\mathrm{Ta}(\mathrm{B})$ & CoY (I) & $\mathrm{Fc}(\mathrm{Sl})$ & $\mathrm{Br}(\mathrm{L})$ \\
\hline & U44 & 1 & Ponnin & $\operatorname{Pr}(\mathrm{S})$ & 3 & $\mathrm{Td}(\mathrm{G})$ & $\mathrm{Lt}(\mathrm{G})$ & $\operatorname{Tp}(\mathrm{G})$ & Fri $(G)$ & $\mathrm{Sb}(\mathrm{Se})$ & $\mathrm{Ta}(\mathrm{B})$ & CoY (Dns) & $\mathrm{Fc}(\mathrm{Sl})$ & $\mathrm{Br}(\mathrm{H})$ \\
\hline & U45 & 2 & Owiro; Orouwiro & $\operatorname{Pr}(\mathrm{S})$ & 2 & $\mathrm{Td}(\mathrm{B})$ & $\mathrm{Lt}(\mathrm{G})$ & $\mathrm{Tp}(\mathrm{G})$ & Fri (B) & $\mathrm{Sb}(\mathrm{Re})$ & $\mathrm{Ta}(\mathrm{B})$ & CoY (Dns) & $\mathrm{Fc}(\mathrm{F})$ & $\mathrm{Br}(\mathrm{H})$ \\
\hline & U46 & 2 & Souhatôn1; Souhatôn2 & $\operatorname{Pr}(\mathrm{S})$ & 5 & $\mathrm{Td}(\mathrm{B})$ & $\mathrm{Lt}(\mathrm{B})$ & $\operatorname{Tp}(\mathrm{G})$ & Fri $(\mathrm{G})$ & $\mathrm{Sb}(\mathrm{Re})$ & $\mathrm{Ta}(\mathrm{G})$ & $\operatorname{CoY}(\mathrm{I})$ & $\mathrm{Fc}(\mathrm{F})$ & $\mathrm{Br}(\mathrm{L})$ \\
\hline & U47 & 1 & Nérica2 & $\operatorname{Pr}(\mathrm{S})$ & 3 & $\mathrm{Td}(\mathrm{G})$ & $\mathrm{Lt}(\mathrm{G})$ & $\mathrm{Tp}(\mathrm{G})$ & Fri $(G)$ & $\mathrm{Sb}(\mathrm{Re})$ & $\mathrm{Ta}(\mathrm{G})$ & $\operatorname{CoY}(\mathrm{I})$ & $\mathrm{Fc}(\mathrm{F})$ & $\mathrm{Br}(\mathrm{L})$ \\
\hline & U48 & 1 & Mongnisouannou & $\operatorname{Pr}(\mathrm{S})$ & 3 & $\mathrm{Td}(\mathrm{B})$ & $\mathrm{Lt}(\mathrm{G})$ & $\mathrm{Tp}(\mathrm{G})$ & Fri $(G)$ & $\mathrm{Sb}(\mathrm{Re})$ & $\mathrm{Ta}(\mathrm{B})$ & CoY (Dns) & $\mathrm{Fc}(\mathrm{Sl})$ & $\mathrm{Br}(\mathrm{L})$ \\
\hline & U49 & 1 & Guibitounga & $\operatorname{Pr}(\mathrm{S})$ & 4 & $\mathrm{Td}(\mathrm{B})$ & $\mathrm{Lt}(\mathrm{G})$ & $\mathrm{Tp}(\mathrm{G})$ & Fri $(\mathrm{G})$ & $\mathrm{Sb}(\mathrm{Re})$ & $\mathrm{Ta}(\mathrm{G})$ & CoY (Dns) & $\mathrm{Fc}(\mathrm{Sl})$ & $\mathrm{Br}(\mathrm{L})$ \\
\hline
\end{tabular}

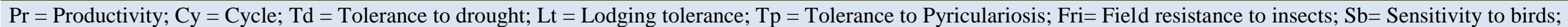

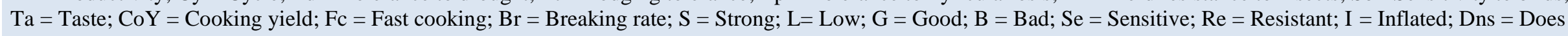
not swell; F = Fast; $\mathrm{Sl}=$ Slow; $\mathrm{H}=$ High; $\mathrm{M}=$ Mouth. 


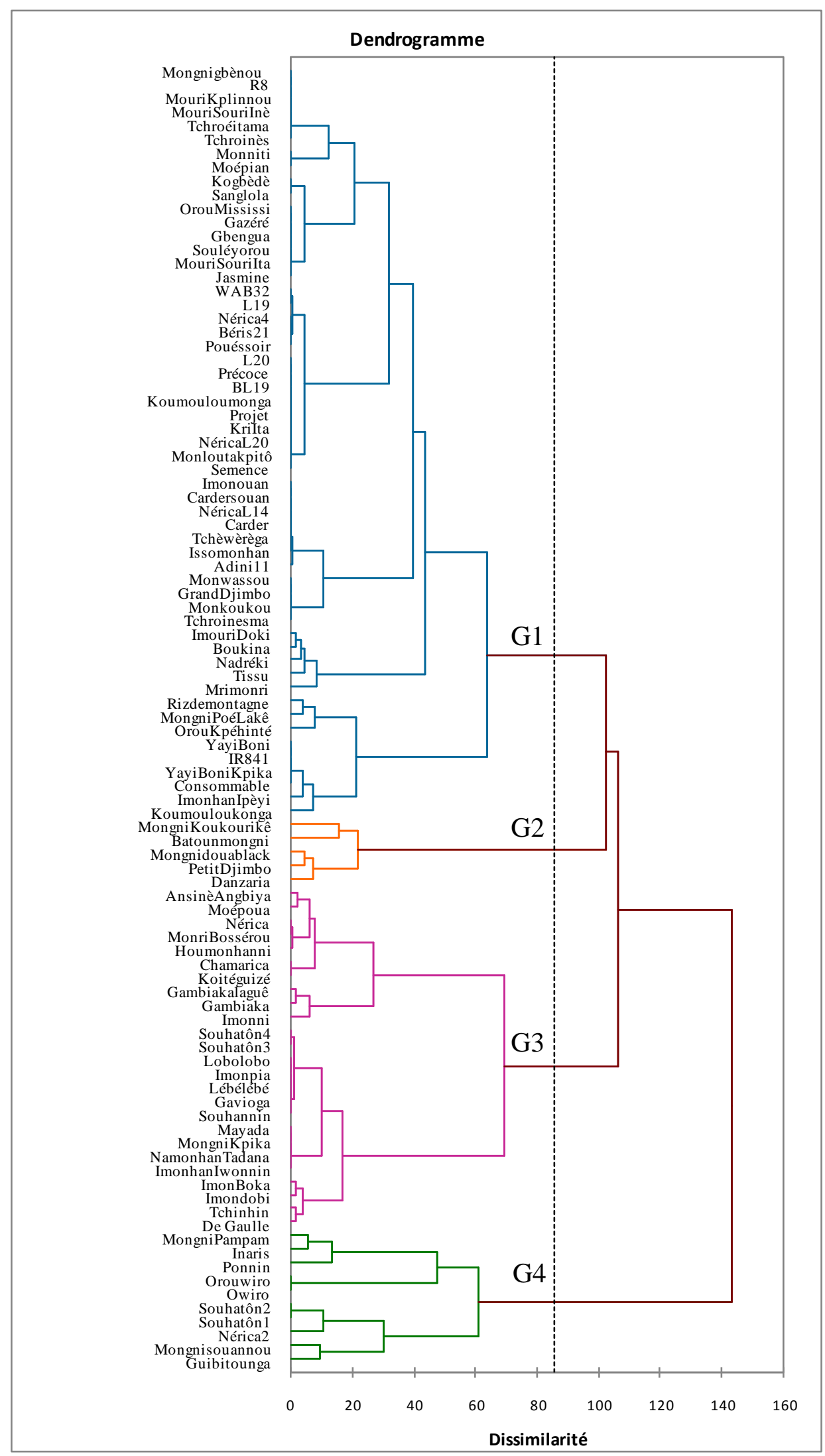

Fig. 3: Dendrogram showing the similarities between the different Groups. 
Table 7. Results of the multiple logistical regression.

\begin{tabular}{llllll}
\hline Settings & $\begin{array}{l}\text { Degree of } \\
\text { freedom }\end{array}$ & Estimated value & $\begin{array}{l}\text { Standard } \\
\text { error }\end{array}$ & Khi-2 de Wald & Pr $>$ Khi-2 \\
\hline Intercept 1 & 1 & 2.2600 & 0.6597 & 11.7355 & 0.0006 \\
Intercept 2 & 1 & 4.2175 & 0.6730 & 39.2663 & $<.0001$ \\
Intercept 3 & 1 & 7.9534 & 0.9719 & 66.9699 & $<.0001$ \\
Sex & 1 & -0.0597 & 0.1453 & 0.1686 & 0.6813 \\
Age & 1 & -0.0223 & 0.00876 & 6.4796 & $0.0109^{*}$ \\
Instruction & 1 & 0.0578 & 0.1518 & 0.1448 & 0.7036 \\
Marital status & 1 & 0.0473 & 0.1444 & 0.1071 & 0.7435 \\
Years of experience & 1 & -0.00199 & 0.0116 & 0.0294 & 0.8638 \\
Household Size & 1 & 0.0356 & 0.0161 & 4.8714 & $0.0273^{*}$ \\
Valid arms & 1 & -0.1272 & 0.0247 & 26.6079 & $<.0001^{* * *}$ \\
Membership in an association & 1 & 0.2812 & 0.1713 & 2.6955 & 0.1006 \\
\hline
\end{tabular}

$(*)$ - Significant; $(* * *)$ - Highly significant.

Table 8. Criteria for variety selection by producers in the study area.

\begin{tabular}{|c|c|c|c|c|c|c|c|c|c|c|}
\hline \multirow{2}{*}{ Category } & \multirow{2}{*}{ Criteria } & \multirow{2}{*}{ Study area } & \multicolumn{8}{|c|}{ Agroecological zones (\%) } \\
\hline & & & I & II & III & IV & $\mathbf{V}$ & VI & VII & VIII \\
\hline \multirow{8}{*}{ Agronomic } & High productivity & 18.22 & 15.46 & 16.47 & 19.85 & 15.13 & 18.79 & 20.37 & 21.85 & 19.62 \\
\hline & Early cycle & 10.48 & 13.40 & 12.19 & 5.28 & 4.16 & 15.71 & 9.05 & 15.42 & 5.74 \\
\hline & Good tillering & 5.64 & 5.15 & 5.67 & 6.56 & 6.05 & 4.29 & 5.76 & 5.91 & 7.42 \\
\hline & Weed Tolerance & 5.46 & 6.19 & 9.09 & 2.73 & 4.92 & 2.35 & 4.94 & 6.43 & 10.53 \\
\hline & Resistance to diseases and pests & 3.96 & 4.12 & 3.53 & 6.92 & 3.53 & 4.29 & 4.12 & 2.57 & 1.91 \\
\hline & Form of grain & 3.80 & 1.55 & 3.21 & 6.92 & 3.53 & 4.29 & 4.12 & 2.57 & 1.91 \\
\hline & Tolerance to drought & 2.86 & 0.00 & 1.93 & 1.09 & 9.84 & 3.32 & 0.00 & 0.00 & 0.00 \\
\hline & Total & 50.43 & 45.88 & 52.09 & 49.36 & 47.16 & 53.04 & 48.35 & 54.76 & 47.13 \\
\hline \multirow{9}{*}{$\begin{array}{l}\text { Culinary and } \\
\text { technological }\end{array}$} & Taste of rice & 6.92 & 18.04 & 6.95 & 0.00 & 0.25 & 6.96 & 10.91 & 10.80 & 15.07 \\
\hline & Aroma & 6.72 & 6.19 & 4.06 & 13.30 & 14.12 & 7.04 & 0.00 & 0.00 & 3.35 \\
\hline & Whiteness of grains & 4.12 & 4.12 & 4.39 & 6.92 & 3.53 & 4.29 & 4.12 & 2.57 & 1.91 \\
\hline & Easy cooking & 4.12 & 4.12 & 4.39 & 6.92 & 3.53 & 4.29 & 4.12 & 2.57 & 1.91 \\
\hline & $\begin{array}{l}\text { Cohesion of grains } \\
\text { after cooking }\end{array}$ & 3.46 & 4.12 & 5.35 & 2.55 & 6.31 & 1.78 & 2.67 & 2.06 & 1.91 \\
\hline & Breaking rate & 3.42 & 4.12 & 5.35 & 2.55 & 6.31 & 1.78 & 2.26 & 2.06 & 1.91 \\
\hline & $\begin{array}{l}\text { Preservation after } \\
\text { cooking }\end{array}$ & 3.14 & 0.00 & 0.00 & 6.92 & 3.53 & 4.29 & 4.12 & 2.57 & 1.91 \\
\hline & Swelling & 3.14 & 4.12 & 5.35 & 2.55 & 6.31 & 1.78 & 2.06 & 0.77 & 0.00 \\
\hline & Total & 35.05 & 44.85 & 35.83 & 41.71 & 43.88 & 32.23 & 30.25 & 23.39 & 27.99 \\
\hline Economic & High Market Value & 14.52 & 9.28 & 12.09 & 8.93 & 8.95 & 14.74 & 21.40 & 21.85 & 24.88 \\
\hline
\end{tabular}

\section{Discussion}

Rice highly contributes to the improvement of food security and household income as farmers produce it for self-consumption and commercialization. This sector, in view of the sizeable areas sown per household, must be well structured for the purposes of food security and poverty reduction. But this crop is unfortunately subject to several constraints that can even be addressed by the use of high-performing varieties (Agré et al., 2015a,b). Researchers must then develop many high-performing varieties to help rice growers cope with the adverse effects of climatic variability, disease (mainly blast and bacteriosis), pests (insects and rodents), and soil poverty, according to Kombo et al. (2012) and Adriano et al. (2013). In the study area, 95 farmers' named varieties of rice were identified. It is very unlikely that these all correspond to different varieties. The vernacular names of crop varieties generally vary from one ethnic group to another, from one village to another within the same ethnic area and sometimes from one household to another within a single village (Dansi et al., 2010; Kombo et al., 2012; Loko et al., 2013). In this context, the same variety across villages can be designated by different names and different varieties can sometimes be referred to by the same name (Tamiru et al., 2008; Otoo et al., 2009).To avoid overestimating or underestimating varietal diversity and to facilitate the 
efficient use of local varieties, these should be collected and characterized both on the basis of morphological and molecular markers (Lekha et al., 2011; Kombo et al., 2012). Despite this great varietal diversity, it is very low compared to that found in the villages of Guinea (Barry et al., 2008) and Madagascar (Radanielina et al., 2013). In fact, Guinea is the center of diversification of cultivated species Oryza glaberrima (Portères, 1956) and is a special place in situ conservation of African rice (Bezançon, 1993). Unfortunately, in Benin, African rice is less represented (2.06\% of the collection) because of its high rate of shattering, low productivity and poor presentation of grain (Sié et al., 1998). But this rice has many qualities such as the ability to smother weeds, tolerance to drought, insects and diseases, the most severe of which is yellow rice or RYMV (Rice Yellow Mottle Virus) (Séré and Sy, 1995; Dingkuhn et al., 1996; Singh, 1996). These qualities could be used in plant breeding programs, so it is important to set up conservation programs of traditional local varieties and especially $O$. glaberrima type (Sié et al., 1998).

The distribution and extent of rice varieties vary from village to village. From the genetic resources conservation point of view, varieties grown by many households over large areas are not threatened and may simply be conserved in situ (Jarvis et al., 2000; Dansi et al., 2010). On the other hand, those cultivated by few households on small areas deserve special attention in terms of conservation. It would be important to collect and preserve them ex situ in genebanks. For the other intermediate stall varieties (few households and large areas, many households and few areas) and following Jarvis et al. (2000) the complementary approach (in situ and ex situ) will be necessary. As in yam in Benin (Loko et al., 2013) and cassava in Congo (Kombo et al., 2012), the average rate of loss of diversity observed in the area is relatively high $(41 \%)$ and indicates Need for urgent action. According to Bonou et al. (2012), this loss of diversity is due either to climate variability, to a disease or to the undesired characteristics of the varieties. For Radanielina et al. (2013), a positive evolution of the production environment could lead to a rapid loss of diversity. A good knowledge of the role of diversity at different scales of management (village, farm, and field) would then be necessary to prevent loss of diversity related to the improvement of the production environment (Barry et al., 2008). A no less important situation is that of land degradation, linked to heavy pressure on land; Rainfed rice is no longer grown every year or is completely abandoned in favor of less demanding crops (Barry et al., 2007): in the absence of cultivation, the varieties disappear. Ongoing monitoring of these dynamics seems necessary to undertake safeguard measures (Barry et al., 2008). The zero rates observed in some villages do not mean better conservation but rather the maximum threshold of varieties abandonment is reached. Similar results have been observed on fonio (Dansi et al., 2010), sorghum (Dossou-Aminon et al., 2015) and cassava (Agré et al., 2015b).

Sociocultural characteristics determine the maintenance of varietal diversity of rice within rice farms. Indeed, the age, the size of the household and the valid arms are factors of maintenance of varietal diversity in Benin. The elder growers retain more varieties than the young (Bonou et al., 2012). These may be associated with in situ conservation programs varieties. In addition, farms with a high household size and able-bodied hold many varieties that leave a wide range of varieties to these farmers in order to meet food and economic needs.

The farmers' variety preferences criteria are not only related to the intrinsic characteristics of the varieties but also to factors related to the biotic and abiotic constraints of production and marketing (Agré et al., 2015b). Among these criteria, the most important are the high productivity and the precocity of the varieties. These results are similar to those of Teshome et al. (2007) and Dossou-Aminon et al. (2015) on sorghum, Ojulong et al. (2010), Kombo et al. (2012) and Agré et al. (2015b) on cassava and Dansi et al. (2013b) on yams. These criteria of economic importance are the most required by breeders and for all crops. The variability of the preference criteria between agro-ecological zones will guide the breeding programs and the varietal exchanges. Earliness is an important preference criterion because it gave producers the guarantee that before rain cuts, a significant level of production would already be reached and a harvest would be possible to satisfy food and economic needs.

\section{Conclusion}

This study carried out in Benin on production constraints, diversity and farmer selection criteria revealed that the production of rice is confronted with several biological constraints that can be overcome by the use of adapted varieties, already existing or to be 
created. The varietal diversity revealed is indicative of the potential for successful breeding programs. However, it will be important to characterize (morphological and molecular characterization) in order to preserve ex situ and on farm the existing diversity.

\section{Conflict of interest statement}

Authors declare that they have no conflict of interest.

\section{Acknowledgement}

This study was carried out under the WAAPP (West Africa Agricultural Productivity Program) project funded by the World Bank. We thank the responsibles of the districts agricultural extension services and the rice producers we met for their technical support.

\section{References}

Adeyemi, P., Vodouhè, S.R., 1996. Amélioration de la productivité des variétés locales de Oryza glaberrima Steud par des croisements intra et interspécifiques avec Oryza sativa Linné. In: Hybridations Interspécifiques au Bénin. ADRAO, Bouaké (Côte d'Ivoire). pp.159-175.

Adriano, S.R., Adenir, V.T., Anilde, G.S., Renato, A.S., 2013. Relative contribution of biotic and abiotic factors to the population density of the cassava green mite, Mononychellus tanajoa (Acari: Tetranychidae). Exp. Appl. Acarol. 276, 14961505.

Agnoun, Y., Samadori, S., Biaou, H., Sié, M., Vodouhè, R.S., Ahanchédé, A., 2012. The African fice Oryza glaberrima Steud: Knowledge, distribution and prospects. Int. J. Biol. 4(3), 158-180.

Agré, A.P., Dansi, A., Rabbi, I.Y., Battachargee, R., Dansi, M., Melaku, G., Augusto, B., Sanni, A., Akouegninou, A., Akpagana, K., 2015a. Agromorphological characterization of elite cassava (Manihot esculenta Crantz) cultivars collected in Benin. Int. J. Curr. Res. Biosci. Plant Biol. 2(2), 114.

Agré, A.P., Kouchade, S., Odjo, T., Dansi, M., Nzobadila, B., Assogba, P., Dansi, A., Akoegninou, A., Sanni, A., 2015b. Diversité et évaluation participative des cultivars du manioc (Manihot esculenta Crantz) au Centre Bénin. Int. J. Biol. Chem. Sci. 9(1), 388-408.

Akakpo, D.A.R., 2011. Caractérisation agromorphologique des écotypes de riz (Oryza spp.) du
Benin. Mémoire d'ingénieur Agronome. Faculté des Sciences Agronomiques. Université d'AbomeyCalavi (République du Bénin) - Ingénieur Agronome 2011. 73p.

Altieri, M.A., Funes-Monzote, F.R., Petersen, P., 2011. Agroecologically efficient agricultural systems for smallholder farmers: Contribution to food sovereignty. Agron. Sustain. Develop. 32, 1-13.

Assogbadjo, A.E., Glèlè Kakaï, R., Adjallala, F.H., Azihou, A.F., Vodouhê, G.F., Kyndt, T., Codjia, J.T.C., 2011. Ethnic differences in use value and use patterns of the threatened multipurpose scrambling shrub (Caesalpinia bonduc L.) in Benin. J. Med. Plant Res. 5(9), 1549-1557.

Barry, M.B., Diagne, A., Pham, J-L., Ahmadi, N., 2008. Évolution récente de la diversité génétique des riz cultivés (Oryza sativa et $O$. glaberrima) en Guinée. Cahiers Agric. 17(2), 122-127.

Barry, M.B., Pham, J.L., Courtois, B., Billot, C., Ahmadi, N., 2007. Rice genetic diversity at farm and village levels and genetic structure of local varieties reveal need for in situ conservation. Genet. Resour. Crop Evol. 54, 1675-1690.

Bezançon, G., 1993. Le riz cultivé d'origine Africaine Oryza sativa Steud, et les formes sauvages et adventices apparentées: Diversité, Relations Génériques et Domestication. Thèse d'Etat, Université Paris-Sud, Orsay. Col. Etude et thèses. ORSTOM, Paris. 232p.

Bonou, A., Diagne, A., Biaou, G., 2012. Impact de l'adoption des Néricas sur la diversité variétale au Bénin. Edition Universitaires Européennes. Edition Janvier 2012. 114p.

Brush, S.B. (Ed.), 2000. Genes in the Field: On-farm Conservation of Crop Diversity. Lewis Publishers, Boca Raton (Florida).

Dagnelie, P., 1998. Statistiques théorique et appliquée. Tome2: inference statistique à une et deux dimensions. De Boeck et Larcier, Pais-Bruxelles, France Belgique. 659p.

Dansi, A., Adoukonou-Sagbadja, H., Vodouhè, R., 2010. Diversity, conservation and related wild species of Fonio millet (Digitaria spp.) in the northwest of Benin. Genet. Resour. Crop Evol. 57(6), 827-839.

Dansi, A., Dantsey-Barry, H., Agré, A.P., DossouAminon, I., Assogba, P., Loko, Y.L., N'Kpenu, E.K., Kombaté, K., Dansi, M., Vodouhè, R., $2013 a$. Production constraints and farmers' cultivar preference criteria of cultivated yams (Dioscorea cayenensis - D. rotundata complex) in Togo. Int. J. Appl. Biol. Pharmaceut. Technol. 4(2), 191-199. 
Dansi, A., Dantsey-Barry, H., Dossou-Aminon, I., N'Kpenu, E.K., Agré, A.P., Sunu, Y.D., Kombate, K., Loko Y.L., Dansi M.,Assogba P., VodouheR., 2013b. Varietal diversity and genetic erosion of cultivated yams (Dioscorea cayenensis Poir.-D. rotundata Lam. complex and D. alata L.) in Togo. Int. J. Biodiv. Conserv. 5(4), 223-239.

Dingkuhn, M., Jones, M.P., Johnson, D.E., Fofana, B., Sow, M., 1996. Hybridation Interspécifique: Vers de nouveaux types de plants faisant échec aux adventices. In: WARDA Rapport Annuel 1995. Bouaké - Côte d'lvoire. pp.29-38.

Dossou-Aminon, I., Dansi, A., Ahissou, H., Cissé, N., Vodouhè, R., Sanni, A., 2015. Climate variability and status of the production and diversity of Sorghum (Sorghum bicolor [L.] Moench) in the arid zone of northwest Benin. Genet. Resour. Crop Evol. 63(7), 1181-1201.

FAO, 2014. Crop Production Statistic. FAOSTAT. FAO, Rome, Italy. 10p.

FAO, 2015. Suivi du marché du riz de la FAO (SMR). FAO, Rome, Italie. 10p.

Frontier, S., Pichod-Viale, D., 1995. Ecosystèmes: Structure, fonctionnement, évolution. Dunod, Paris.

Gbaguidi, A.A., Dansi, A., Loko, L.Y., Dansi, M., Sanni, A., 2013. Diversity and agronomic performances of the cowpea (Vigna unguiculata Walp.) landraces in Southern Benin. Int. Res. J. Agric. Sci. Soil Sci. 3(4), 121-133.

INSAE, 2013. Résultats provisoires du RGPH4. Institut National de la Statistique et de l'Analyse Economique, Cotonou, Bénin. 8p.

Jackson, L., von Noordwijk, M., Bengtsson, J., Foster, W., Lipper, L., Pulleman, M., 2010. Biodiversity and agricultural sustainability: From assessment to adaptive management. Curr. Opin. Environ. Sustain. 2, 80-87.

Jarvis, D., Myer, L., Klemick, H., Guarino, L., Smale, M., Brown, A.H.D., Sadiki, M., Sthapit, B., Hodgkin, T., 2000. A Training Guide for In Situ Conservation On-Farm (Version 1). Rome, Italy.

Jarvis, D.I., Padoch, C., Cooper, H.D., 2007. Managing Biodiversity in Agricultural Ecosystems. Columbia University Press, New York. 449p.

Kombo, G.R., Dansi, A., Loko, L.Y., Orkwor, G.C., Vodouhè, R., Assogba, P., Magema, J.M., 2012. Diversity of cassava (Manihot esculenta Crantz) cultivars and its management in the department of Bouenza in the Republic of Congo. Genet. Resour. Crop Evol. 59(8), 1789-1803.
Legendre, L., Legendre, P., 1984. Ecologie numérique. Tome 2: La structure des donnéesécologiques. Masson collection d'écologie $\mathrm{n}^{\circ} 13$.

Lekha, S.S., Teixeira da Silva, J.A., Pillai, S.V., 2011. Genetic variability studies between released varieties of cassava and central Kerala cassava collections using SSR markers. J. Stored Prod. Postharv. Res. 2(4), 79-92.

Loko, Y.L., Dansi, A., Linsoussi, C., Tamo, M., Vodouhè, R., Akoegninou, A., Sanni, A., 2013. Current status and spatial analysis of Guinea yam (Dioscorea cayenensis Lam. -D. rotundata Poir. complex) diversity in Benin. Int. Res. J. Agric. Sci. Soil Sci. 3(7), 219-238.

MAEP (Ministère de l'Agriculture de l'Elevage et de la Pêche), 2013. Evolution de réalisations des principales cultures par commune (Période: 19982010), MAEP, Bénin.

Ojulong, H.F., Labuschagne, M.T., Herselman, L., Fregene, M., 2010. Yield traits as selection indices in seedling populations of cassava. Crop Breed. Appl. Biotechnol. 10(3), 14-26.

Orobiyi, A., Dansi, A., Assogba, P., Loko, L.Y., Dansi, M., Vodouhè, R., Akouègninou, A., Sanni, A., 2013. Chili (Capsicum annuum L.) in southern Benin: Production constraints, varietal diversity, preference criteria and participatory evaluation. Int. Res. J. Agric. Sci. Soil Sci. 3(4), 107-120.

Otoo, E., Akromah, R., Kololesnikova-Allen, M., Asiedu, R., 2009. Ethno-botany and morphological characterisation of the yam pona complex in Ghana. Afr. Crop Sci. 9, 407-414.

Portères, R., 1956. Taxonomie agrobotanique des riz cultivés $O$. sativa Linné et $O$. glaberrima Steudcl. Compilation d'articles du JATBA. Museum National d'histoire naturelle, Paris.

Radanielina, T., Ramanantsoanirina, A., Raboin, L-M., Ahmadi, N., 2013. Déterminants de la diversité variétale du riz dans la région de Vakinankaratra (Madagascar). Cahierd'Agric. 22(5), 442-449.

Roy, S., Marndi, B.C., Mawkhlieng, B., Banerjee, A., Yadav, R.M., Misra, A.K., Bansal, K.C., 2016. Genetic diversity and structure in hill rice (Oryza sativa L.) landraces from the North-Eastern Himalayas of India. BMC Genet. 17, 107.

Saïto, K., Dieng, I., Toure, A., Somado, E.A., Wopereis, M.C.S., 2015. Rice yield growth analysis for 24 African countries over 1960-2012. Glob. Food Secur. 5, 62-69.

Seck, P., Diagne, A., Mohanty, S., Wopereis, M.S., 2012. Crops that feed the world 7: Rice. Food Sec. 4, 7-24. 
Séré, Y., Sy, A.A., 1995. Situation phytosanitaire du riz: Caractérisation des affectations majeures; First International Symposium on Rice Yellow Moule Virus (September 18-22, Bouaké, Côte d'Ivoire).

Shannon, C.E., Weaver, W., 1948. A mathematical theory of communication. Bell System Technical J. 27, 379-423.

Sié, M., Zongo, J. D., Dakouo, D., 1998. Prospection des cultivars traditionnels de riz du Burkina Faso. Revue CAMES Volume $\mathrm{N}^{\circ} 00$ - 1998.

Singh, B.N., 1996. Varietal resistance to rice yellow moitie virus in lowland rice. In: Irrigated Rice in the Sahel: Prospects for Sustainable Development (Eds.: Miézan, K.M., Wopereis, M.C.S., Dingkuhn, M., Deckers, J., Randolph, T.F). Proceedings of International Symposium held at WARDA's research station in N'Diaye, Scnegal (27-30 March 1995). pp.457-463.

Tamiru, M., Becker, C.H., Maas, B.L., 2008. Diversity, distribution and management of yam landraces (Dioscorea spp.) in Southern Ethiopia. Genet. Resour. Crop Evol. 55, 115-131.

Teshome, A., Patterson, D., Asfew, Z., Torrance, J.K., Arnason, J.T., 2007. Changes of Sorghum bicolor landrace diversity and farmers' selection criteria over space and time, Ethiopia. Genet. Resour. Crop Evol. 54(6), 1219-1233.

USDA, 2013. Production, Supply and Distribution (PSD) online [database]. Foreign Agricultural Service, United States Department of Agriculture 〈http://www.fas. usda.gov/psdonline/〉 (accessed April 20, 2013).

\section{How to cite this article:}

Odjo, T.C., Dossou-Aminon, I., Dansi, A., Djengue, H. W., 2017. Diversity, genetic erosion and participatory evaluation of rice (Oryza sativa L.and Oryza glaberrima Steud) varieties in Benin. Int. J. Curr. Res. Biosci. Plant Biol. 4(4), 147-164. doi: https://doi.org/10.20546/ijcrbp.2017.404.021 